\title{
Laquinimod protects the optic nerve and retina in an experimental autoimmune encephalomyelitis model
}

\author{
Anna T. Wilmes ${ }^{1 \dagger}$, Sabrina Reinehr ${ }^{1 \dagger}$, Sandra Kühn ${ }^{1}$, Xiomara Pedreiturria ${ }^{2}$, Laura Petrikowski ${ }^{2}$, Simon Faissner ${ }^{2}$, \\ Ilya Ayzenberg ${ }^{2}$, Gesa Stute ${ }^{1}$, Ralf Gold ${ }^{2}$, H. Burkhard Dick ${ }^{1}$ Ingo Kleiter ${ }^{2^{*+}}$ and Stephanie C. Joachim ${ }^{1^{*+}}$
}

\begin{abstract}
Background: The oral immunomodulatory agent laquinimod is currently evaluated for multiple sclerosis (MS) treatment. Phase II and III studies demonstrated a reduction of degenerative processes. In addition to anti-inflammatory effects, laquinimod might have neuroprotective properties, but its impact on the visual system, which is often affected by MS, is unknown. The aim of our study was to investigate potential protective effects of laquinimod on the optic nerve and retina in an experimental autoimmune encephalomyelitis (EAE) model.

Methods: We induced EAE in C57/BL6 mice via $\mathrm{MOG}_{35-55}$ immunization. Animals were divided into an untreated EAE group, three EAE groups receiving laquinimod $(1,5$, or $25 \mathrm{mg} / \mathrm{kg}$ daily), starting the day post-immunization, and a nonimmunized control group. Thirty days post-immunization, scotopic electroretinograms were carried out, and mice were sacrificed for histopathology (HE, LFB), immunohistochemistry (MBP, Iba1, Tmem119, F4/80, GFAP, vimentin, Brn-3a, cleaved caspase 3) of the optic nerve and retina, and retinal qRT-PCR analyses (Brn-3a, Iba1, Tmem119, AMWAP, CD68, GFAP). To evaluate the effect of a therapeutic approach, EAE animals were treated with $25 \mathrm{mg} / \mathrm{kg}$ laquinimod from day 16 when $60 \%$ of the animals had developed clinical signs of EAE.

Results: Laquinimod reduced neurological EAE symptoms and improved the neuronal electrical output of the inner nuclear layer compared to untreated EAE mice. Furthermore, cellular infiltration, especially recruited phagocytes, and demyelination in the optic nerve were reduced. Microglia were diminished in optic nerve and retina. Retinal macroglial signal was reduced under treatment, whereas in the optic nerve macroglia were not affected. Additionally, laquinimod preserved retinal ganglion cells and reduced apoptosis. A later treatment with laquinimod in a therapeutic approach led to a reduction of clinical signs and to an improved b-wave amplitude. However, no changes in cellular infiltration and demyelination of the optic nerves were observed. Also, the number of retinal ganglion cells remained unaltered.

Conclusion: From our study, we deduce neuroprotective and anti-inflammatory effects of laquinimod on the optic nerve and retina in EAE mice, when animals were treated before any clinical signs were noted. Given the fact that the visual system is frequently affected by MS, the agent might be an interesting subject of further neuro-ophthalmic investigations.
\end{abstract}

Keywords: Multiple sclerosis, Laquinimod, EAE, Optic nerve, Inflammation, Demyelination, Retinal degeneration, Glia response, Protection, Electroretinogram

\footnotetext{
* Correspondence: ingo.kleiter@rub.de; stephanie.joachim@rub.de

${ }^{\dagger}$ Anna T. Wilmes, Sabrina Reinehr, Ingo Kleiter and Stephanie C. Joachim

contributed equally to this work.

${ }^{2}$ Department of Neurology, St. Josef-Hospital, Ruhr-University Bochum,

Gudrunstrasse 56, 44791 Bochum, Germany

${ }^{1}$ Experimental Eye Research Institute, University Eye Hospital, Ruhr-University

Bochum, In der Schornau 23-25, 44892 Bochum, Germany
}

(C) The Author(s). 2018 Open Access This article is distributed under the terms of the Creative Commons Attribution 4.0 International License (http://creativecommons.org/licenses/by/4.0/), which permits unrestricted use, distribution, and

reproduction in any medium, provided you give appropriate credit to the original author(s) and the source, provide a link to the Creative Commons license, and indicate if changes were made. The Creative Commons Public Domain Dedication waiver (http://creativecommons.org/publicdomain/zero/1.0/) applies to the data made available in this article, unless otherwise stated. 


\section{Background}

Multiple sclerosis (MS) is a neurodegenerative and inflammatory disease of the central nervous system affecting more than 2.5 million people worldwide [1, 2]. The precise etiology of MS is not fully understood. Research of the past decades indicates a multifactorial background, comprising an impact of genetics, environmental factors, and gender [3].

The most important pathomechanism in MS is an autoimmune demyelination which is linked to inflammatory cell migration and the formation of central nervous system (CNS) white matter lesions [4]. Glial activation and lymphocytic infiltration play an important role in this process [5]. Clinically, MS patients display a large variety of symptoms [6]. As an evolutionary part of the $\mathrm{CNS}$, the eye is also frequently involved. Optic neuritis, mainly unilateral, is the initial symptom in appr. $30 \%$ of MS patients and affects 60 to $70 \%$ in the later course [7]. It can manifest as subacute vision impairment up to complete loss of vision, central scotoma, diminished color vision, decreased contrast sensitivity, and retrobulbar pain during eye movement $[5,7,8]$. Papilledema and a relative afferent pupillary defect give diagnostic clues in ophthalmic examination [7, 9]. Recovery from optic neuritis is common, yet residual deficits can remain and impact quality of life $[10,11]$.

In MS research, experimental autoimmune encephalomyelitis (EAE) is the most common animal model. EAE is induced by immunization with CNS-specific antigens [12]. A murine EAE model, with myelin oligodendrocyte glycoprotein $(\mathrm{MOG})_{35-55}$ as antigen, is known to induce chronic-progressive disease courses in C57BL/6 mice and affects spinal cord and optic nerves [13]. In the optic nerve, EAE is accompanied with demyelination and inflammatory cell infiltration [14-16]. Additionally, increased numbers of microglia in both optic nerve and retina [17], and a decrease of retinal ganglion cells [15] are common.

The oral drugs fingolimod, dimethyl fumarate, and teriflunomide have recently been introduced as MS therapies and are already broadly applied [18]. Another oral substance currently developed for MS is laquinimod, a quinoline-3-carboxamide [19]. Immunomodulatory, anti-inflammatory, and neuroprotective effects were observed in several EAE models [20-22]. In line with these results, phase II and phase III clinical trials demonstrated a reduction of active MRI lesions, less brain atrophy, and lower annualized relapse rates as well as less progression of disability in MS patients receiving laquinimod [23-25].

It is unknown whether inflammatory demyelination in the visual system, a crucial spot of manifestation in MS, is also affected by laquinimod therapy. This study aims at investigating therapeutic effects of laquinimod when applied at two different points in time on optic nerve and retina in a murine model of MS.

\section{Methods \\ Animals}

All experiments that involved animals were performed in compliance with the ARVO statement for the Use of Animals in Ophthalmic and Vision Research and approved by the animal care committee of North Rhine-Westphalia, Germany. C57BL/6 mice (Janvier, Paris, France) were housed in our facility under environmentally controlled conditions with free access to food and water ad libitum in the absence of pathogens.

\section{Induction and evaluation of EAE}

To induce EAE, 10-weeks-old C57BL/6 mice (wild type) were immunized subcutaneously with $100 \mu \mathrm{g}_{\mathrm{MOG}} \mathrm{M}_{35} 5$ peptide (provided by Charité, Berlin, Germany) in complete Freund's adjuvant (BD Difco, Franklin Lakes, NJ, USA) containing $100 \mu \mathrm{g}$ mycobacterium tuberculosis H37Ra (BD Difco). Additionally, mice received $500 \mathrm{ng}$ pertussis toxin (Merck Millipore, Darmstadt, Germany) intraperitoneally on days 0 and 2 [26].

Immunized animals were divided into the following groups: one untreated EAE group and three EAE groups receiving laquinimod (Selleckchem, Munich, Germany) in doses of 1,5 , or $25 \mathrm{mg} / \mathrm{kg}$ body weight, respectively. Laquinimod was dissolved in $200 \mu \mathrm{H} \mathrm{H}_{2} \mathrm{O}$ and administered orally once per day, starting from the day after immunization. A non-immunized control group received PBS instead of $\mathrm{MOG}_{35-55}$ peptide and $200 \mu \mathrm{l} \mathrm{H}_{2} \mathrm{O}$ daily as a stress equivalent. 11-12 animals/group were analyzed. To investigate the effect of delayed treatment, animals were immunized with $\mathrm{MOG}_{35-55}$ peptide, as described above. When $60 \%$ of the animals had developed clinical signs of EAE (day 16), they were divided in two groups: $\operatorname{EAE}(n=3)$ and Laq $(n=5)$. The animals in the Laq group received $25 \mathrm{mg} / \mathrm{kg}$ laquinimod.

Clinical assessment of EAE was performed daily, using a 10-point score system [27]: $0=$ normal, $1=$ less lively, $2=$ impaired righting/limp tail, $3=$ absent righting, $4=$ ataxic gait, abnormal position, $5=$ mild paraparesis, $6=$ moderate paraparesis, $7=$ severe paraplegia, $8=$ tetraparesis, $9=$ moribund, and 10 = death. Thirty days after MOG immunization, mice were sacrificed. For histology and immunohistochemistry, mice were perfused with $4 \%$ paraformaldehyde (Sigma-Aldrich, Munich, Germany), and the eyes and optic nerves were removed, post-fixed in $4 \%$ paraformaldehyde (Merck, Darmstadt, Germany), drained in 30\% sucrose (VWR, Langenfeld, Germany), embedded in Tissue Tec (Thermo Scientific, Cheshire, UK) and frozen at $-80{ }^{\circ} \mathrm{C}$. The retinas used for the qRT-PCR were isolated from the surrounding tissue and frozen at $-80{ }^{\circ} \mathrm{C}$. 


\section{Electroretinograms}

For scotopic electroretinogram (ERG) measurements, we monitored retinal function using full-field flash electroretinography (HMsERG system; OcuScience LLC, Rolla, MO, USA) 30 days after immunization in both studies [28]. ERGs were recorded at $0.1,0.3,1,3,10$, and $25 \mathrm{~cd} . \mathrm{s} / \mathrm{m}^{2}$. After amplification, digitalization, and averaging of signals, ERGView software (Version 4.380R; OcuScience LLC) was applied to evaluate $\mathrm{a}$ - and $\mathrm{b}$-wave amplitudes.

\section{Histopathological staining and scoring of optic nerve}

Longitudinal cryo-sections of optic nerves $(4 \mu \mathrm{m}, 1$ nerve/ animal) were stained with hematoxylin and eosin (HE; Merck) or luxol fast blue (LFB; RAL Diagnostics, Martillac Cedex, France) in both studies. Three images of each optic nerve section (anterior, medial, posterior) were taken with an Axio Imager M1 microscope (Zeiss, Oberkochen, Germany) at a $\times 400$ magnification (six sections per animal).

After masking with a random number code via Ant Renamer software (http://antp.be/software/renamer), pictures were evaluated. The extent of inflammatory cell infiltration was measured using an established 4-point score on the HE-stained sections [15, 29]: $0=$ no infiltration, $1=$ mild infiltration, $2=$ moderate infiltration, $3=$ severe infiltration, and 4 = massive infiltration with formation of cellular conglomerates. The degree of demyelination in LFB-stained sections was assessed as $0=$ no demyelination, $1=$ moderate demyelination, and $2=$ severe demyelination [15].

\section{Immunohistochemistry of optic nerve and retina}

Immunohistochemistry of longitudinal sections of the optic nerve $(4 \mu \mathrm{m}$, one nerve/animal) and retinal cross-sections $(10 \mu \mathrm{m}$, one retina/animal) was conducted as previously described [17]. Primary and secondary antibodies are listed in Table 1. Six sections per animal were used for each staining. In the optic nerve, three photos and in the retina, four photos per section were taken using the Axio Imager M1 microscope (Zeiss) for myelin basic protein (MBP) and GFAP staining in the optic nerve and the ApoTome.2 microscope (Zeiss) for all other stainings with a $\times 400$ magnification, respectively. Again, all images were masked with a random number code using Ant Renamer software and cut with a predefined window (Corel Paint Shop Pro, V13; Corel Corporation; Ottawa, Canada).

Two different types of analyses were performed, both using Image software (1.48v; Wayne Rasband National Institutes of Health, USA). With the first type, signal areas of MBP and GFAP in the optic nerve and of GFAP and vimentin in the retina were measured using an ImageJ macro [30, 31]. Briefly, the macro was set as follows: after transforming every photo into gray scale (32 bit), the level of background subtraction was averaged (MBP 14.47 pixels; GFAP optic nerve: 22.95 pixels, GFAP retina: 233.2 pixels; vimentin $=421$ pixels) and the mean lower and upper threshold determined (MBP: lower threshold = 2.58, upper threshold $=33.33$; GFAP optic nerve: lower threshold $=4.42$, upper threshold $=60.91$; GFAP retina: lower threshold $=10.08$, upper threshold $=126.76$; vimentin: lower threshold $=4.28$, upper threshold $=93.51)$. Signals were measured as percentage of area. Regarding stainings of Brn-3a, cleaved caspase 3, Iba1, Tmem119, and F4/80, a second type of analysis was used: all cells labeled with the respective marker were counted with Image J cell counter (intern plugin of version $1.48 \mathrm{v}$ ) in a masked fashion [32].

Table 1 Antibodies used on optic nerve and retina for immunohistochemistry

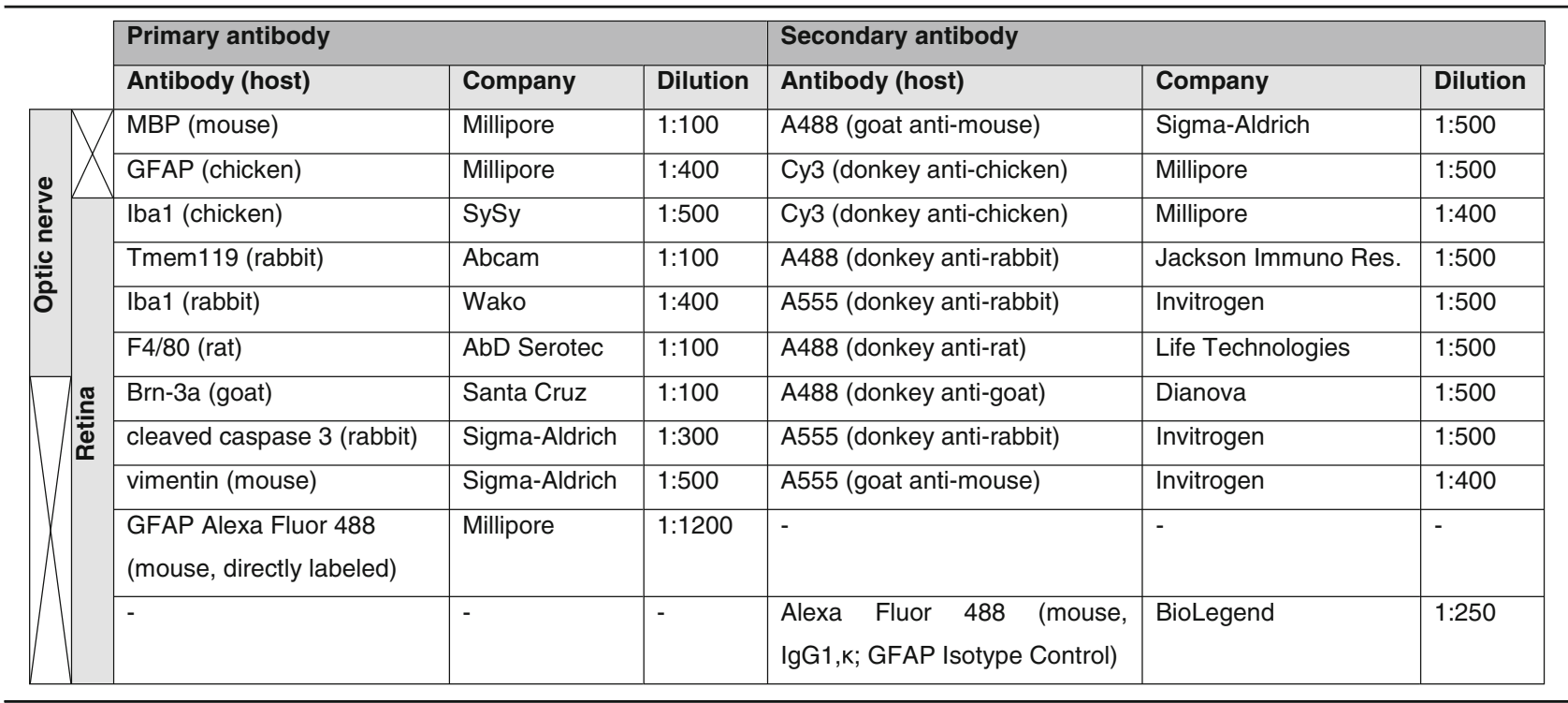


Retinal quantitative real-time reverse transcription polymerase chain reaction

Both retinas of each animal were pooled for RNA preparation and cDNA synthesis as previously described [33]. The designed oligonucleotides for the quantitative real-time-PCR (qRT-PCR) are shown in Table 2. The qRT-PCR was performed using DyNAmo Flash SYBR Green (Thermo Scientific) on the PikoReal qRT-PCR Cycler (Thermo Scientific).

\section{Statistical analyses}

Statistical analyses were carried out using Statistica software (V13; DELL, Tulsa, OK, USA) for ERGs and immunohistochemistry: groups were compared to each other by one-way ANOVA, followed by post hoc Tukey HSD test. HE and LFB score statistics comprised Kruskal-Wallis test followed by Dunn's test using Graph Pad Prism 5 (San Diego, CA, USA). For qRT-PCR, statistical evaluation of threshold cycle $(\mathrm{Ct})$ variations, and calculated relative expression variations, groups were analyzed by a pairwise fixed reallocation and randomization test using REST(C) software (Qiagen, Hilden, Germany) [34]. In the therapeutic treatment paradigm, EAE, LFB, and HE scores were evaluated using a non-parametric Mann-Whitney $U$ test (Statistica) and ERGs and immunohistochemistry were compared using Student's $t$ test (Statistica). $P$ values $<0.05$ were considered as statistically significant. Data are presented as mean \pm standard deviation (SD) for EAE scores, ERGs and immunohistochemistry and as median, interquartile range and range for qRT-PCR, and HE and LFB scores. Data of

Table 2 Primer pairs for qRT-PCR analysis

\begin{tabular}{ll}
\hline Oligonucleotides & Sequence 5' to $3^{\prime}$ \\
\hline B-actin_fwd & ctaaggccaaccgtgaaaag \\
B-actin_rev & accagaggcatacagggaca \\
Brn-3a_fwd & ctccctgagcacaagtaccc \\
Brn-3a_rev & ctggcgaagaggttgctc \\
CD68_fwd & tgatcttgctaggaccgctta \\
CD68_rev & taacggccttttgtgagga \\
Cyclophilin_fwd & ttcttcataaccacagtcaagacc \\
Cyclophilin_rev & tccaccttccgtaccacatc \\
Iba1_fwd & ggatttgcagggaggaaaa \\
Iba1_rev & tgggatcatcgaggaattg \\
GFAP_fwd & acagactttctccaacctccag \\
GFAP_rev & ccttctgacacggatttggt \\
Tmem119_fwd & gtgtctaacaggccccagaa \\
Tmem119_rev & agccacgtggtatcaaggag \\
AMWAP_fwd & tttgatcactgtggggatga \\
AMWAP_rev & acactttctggtgaaggcttg \\
\hline The primer pairs & asted in the tablewexperiments. 3 -actin
\end{tabular}

The primer pairs listed in the table were used in qRT-PCR experiments. B-actin and cyclophilin served as housekeeping genes for retinal samples. Fwd forward, rev reverse the second were presented as mean $\pm \mathrm{SD} \pm$ standard error (SEM) for ERG, HE and LFB scores and immunohistochemistry and as mean \pm SD for EAE scores.

\section{Results}

Fewer neurological symptoms in mice receiving laquinimod

Mice developed clinical signs of EAE starting at day 16 after $\mathrm{MOG}_{35-55}$ immunization (Fig. 1a). The average score of EAE mice increased up to a plateau phase with its peak at days 21-23 (mean score day 21: 4.9 \pm 2.7 ), equivalent with an ataxic gait and mild paraparesis of hind limbs. From day 25 on, a partial remission of disease was observed. In contrast to EAE mice, mice treated with laquinimod showed less neurological deficits. Their highest EAE scores measured $0.6 \pm 1.5$ for the $1 \mathrm{mg} / \mathrm{kg}$ laquinimod group (days 19-29), $1.5 \pm 2.5$ for the $5 \mathrm{mg} / \mathrm{kg}$ laquinimod group (day 28), and $0.0 \pm 0.0$ for the $25 \mathrm{mg} / \mathrm{kg}$ laquinimod group (all days). From days 19 to 29, EAE scores of treated groups were significantly lower than those of the EAE group with the most significant difference in the EAE plateau phase (days 20 to 24; $p<0.001$ for all treated groups).

\section{Better electrical output of the inner nuclear layer in laquinimod-treated mice}

A-wave and b-wave amplitudes were evaluated via ERG recording. The a-wave amplitude (Fig. 1b) represents the electrical output of photoreceptors. In the untreated EAE group, the a-wave amplitude was significantly reduced at $3 \mathrm{~cd} \mathrm{~s} / \mathrm{m}^{2}$ flash intensity compared to the control group. Laquinimod-treated groups showed a slight but non-significant trend for improved electrical conductivity at all flash intensities compared to the untreated EAE group. No other effects on a-wave courses were measured. However, there were significant differences regarding the b-wave amplitude (Fig. 1c), which mirrors the electrical output of neurons of the inner nuclear layer. In the EAE group, the b-wave amplitude was strongly reduced at all flash intensities compared to the control group. Application of $5 \mathrm{mg} / \mathrm{kg}$ laquinimod constantly improved the electrical output in comparison to the untreated EAE group: the b-wave amplitude was significantly increased at flash intensities of 0.1 up to $3 \mathrm{~cd} \mathrm{~s} / \mathrm{m}^{2}$ and an increasing trend was seen for the 10 and $25 \mathrm{~cd} \mathrm{~s} / \mathrm{m}^{2}$ flashes. The $25 \mathrm{mg} / \mathrm{kg}$ laquinimod group displayed a significantly improved b-wave amplitude compared to the untreated EAE group at a flash intensity of $1 \mathrm{~cd} \mathrm{~s} / \mathrm{m}^{2}$.

\section{Less cellular infiltration in the optic nerve with highly dosed laquinimod}

Sections of optic nerve tissue were stained with $\mathrm{HE}$ (Fig. 2a) and scored to evaluate the degree of cellular 


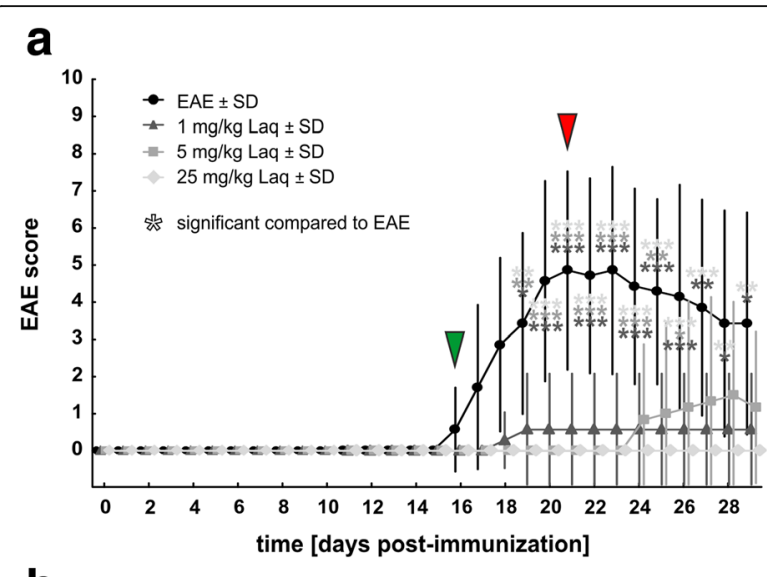

b

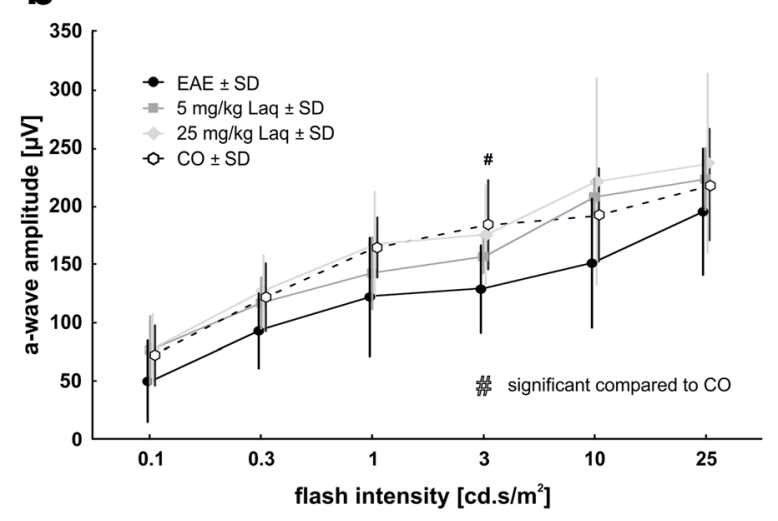

C

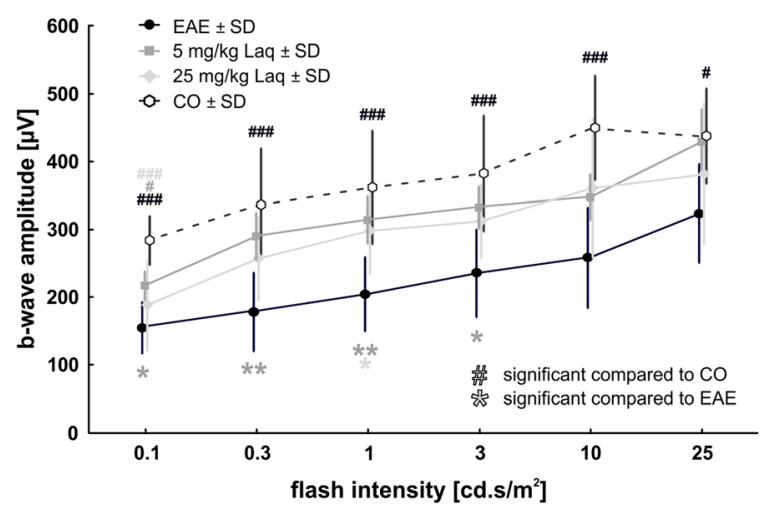

Fig. 1 Clinical effects of laquinimod treatment. a Mean clinical EAE scores after immunization with $\mathrm{MOG}_{35-55}$ peptide. Green arrowhead: onset of symptoms. Red arrowhead: symptoms' peak. b Electroretinograms were measured at the end of the experiment at day 30 . A-wave amplitudes illustrate conductivity of photoreceptors. c B-wave amplitudes illustrate conductivity of the inner nuclear layer. Values represent mean $\pm S D$. Oneway ANOVA and Tukey post hoc. $N=6-7 /$ group in $\mathbf{a}$ and $n=5 /$ group in

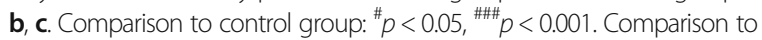
untreated EAE group: ${ }^{*} p<0.05,{ }^{* *} p<0.01,{ }^{* * *} p<0.001$

infiltration. The EAE group showed significantly more cellular infiltration, with a median score of 2.1 (interquartile range (IQR) 1.9-2.5) compared to the control group with a score of 0.6 (IQR 0.6-0.7; $p<0.01$ ) (Fig. 2b). Application of $25 \mathrm{mg} / \mathrm{kg}$ laquinimod significantly decreased the cellular infiltration score to 1.0 (IQR $0.6-1.4 ; p<0.05$ ) in comparison to the EAE group. Smaller doses of laquinimod did not reduce cellular infiltration ( $1 \mathrm{mg} / \mathrm{kg}: 1.9$, IQR $1.7-2.6 ; 5 \mathrm{mg} / \mathrm{kg}$ : 1.9, IQR 1.3-2.1; both $p>0.05$ versus untreated EAE mice).

\section{Less demyelination in the optic nerve with highly dosed laquinimod}

Histopathological investigations on optic nerve tissue also included LFB staining (Fig. 2a) followed by scoring to analyze the extent of demyelination. In the EAE group, a higher demyelination score of 1.7 (IQR 1.6-1.8) was found compared to the control group score of 0.8 (IQR 0.6-1.1; $p<0.01$; Fig. 2c). Administration of laquinimod in the dose $25 \mathrm{mg} / \mathrm{kg}$ significantly diminished the degree of demyelination compared to the EAE group (0.9, IQR $0.7-1.1 ; p<0.01)$, whereas medication with 1 and $5 \mathrm{mg} / \mathrm{kg}$ laquinimod revealed no significant reduction of demyelination $(1 \mathrm{mg} / \mathrm{kg}: 1.5$, IQR $1.2-1.9 ; 5 \mathrm{mg} / \mathrm{kg}: 1.3$, IQR 1.0-1.4, both $p>0.05$ ).

Myelin sheaths were also analyzed via myelin basic protein (MBP) labeling (Fig. 2a). The control group showed significantly more MBP signal $(50.0 \pm 5.1 \%$ / image), meaning preserved myelin, than all other groups (EAE: $27.5 \pm 6.9 \% /$ image, $p<0.001 ; 1 \mathrm{mg} / \mathrm{kg}: 27.6 \pm 7.4 \% /$ image, $p<0.001 ; 5 \mathrm{mg} / \mathrm{kg}$ : $35.8 \pm 11.9 \% /$ image, $p=0.022$; $25 \mathrm{mg} / \mathrm{kg}: 34.5 \pm 4.3 \% /$ image, $p=0.011$; Fig. $2 \mathrm{~d}$ ).

\section{Less microglia and recruited phagocytes in the optic nerve under laquinimod treatment}

All phagocytes were labeled with an Ibal antibody. The co-staining with Tmem119 antibody was used to differentiate between resident microglia and recruited phagocytes [35] (Fig. 3a).

In the optic nerve, EAE animals presented significantly more Iba1 ${ }^{+}$cells than the control group $(393.2 \pm 67.7$ cells/ $\mathrm{mm}^{2}$ versus $57.8 \pm 21.2$ cells $/ \mathrm{mm}^{2} ; p<0.001$ ) (Fig. 3b). Administration of laquinimod significantly reduced their number compared to EAE animals ( $1 \mathrm{mg} / \mathrm{kg}: 285.8 \pm 95.4$ cells/ $\mathrm{mm}^{2}, p=0.045 ; 5 \mathrm{mg} / \mathrm{kg}: 156.4 \pm 69.6$ cells $/ \mathrm{mm}^{2}, p<0.001$; $25 \mathrm{mg} / \mathrm{kg}: 87.4 \pm 55.0$ cells $\left./ \mathrm{mm}^{2}, p<0.001\right)$.

Microglia $\left(\mathrm{Tmem}^{+}\right.$and $\mathrm{Iba}^{+}$, Fig. 3c) formed a smaller part of all $\mathrm{Iba}^{+}$cells than infiltrating phagocytes $\left(\mathrm{Tmem}^{-}\right.$and $\mathrm{Iba}^{+}$, Fig. $\left.3 \mathrm{~d}\right)$. In the EAE group, significantly more microglia $\left(\mathrm{Tmem}^{+}\right.$and $\left.\mathrm{Ibal}^{+}\right)$were detected than in the control group $\left(134.7 \pm 49.4\right.$ cells $/ \mathrm{mm}^{2}$ versus $17.0 \pm 11.0$ cells $\left./ \mathrm{mm}^{2} ; p<0.001\right)$. All laquinimod-treated groups showed significantly less $\mathrm{Tmem}^{+}$and $\mathrm{Iba}^{+}$cells compared to EAE mice $\left(1 \mathrm{mg} / \mathrm{kg}: 77.5 \pm 32.2\right.$ cells $/ \mathrm{mm}^{2}$, $p=0.009 ; 5 \mathrm{mg} / \mathrm{kg}: 27.4 \pm 14.2$ cells $/ \mathrm{mm}^{2}, \quad p<0.001$; $25 \mathrm{mg} / \mathrm{kg}: 23.0 \pm 12.1$ cells $/ \mathrm{mm}^{2}, p<0.001$ ).

Similar results were observed for recruited phagocytes: the EAE group had significantly more $\mathrm{Tmem}^{-}$and $\mathrm{Iba}^{+}$ cells than the control group $\left(258.5 \pm 72.2\right.$ cells $/ \mathrm{mm}^{2}$ 


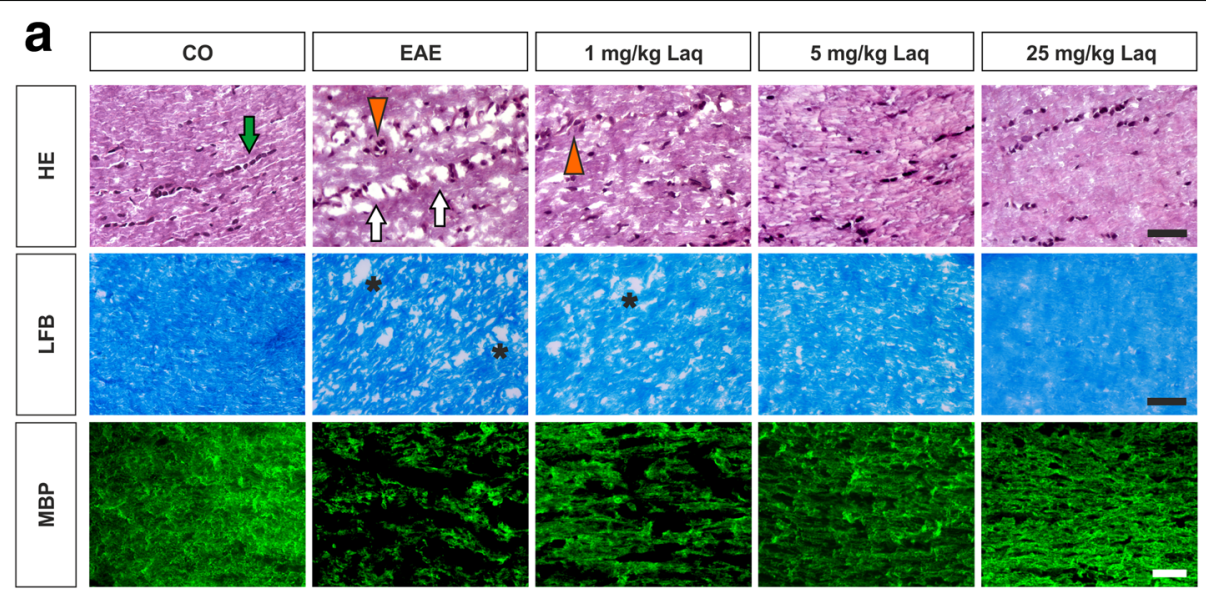

b

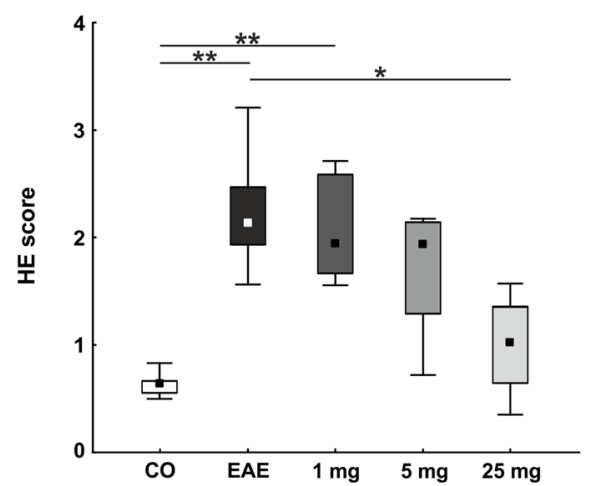

C

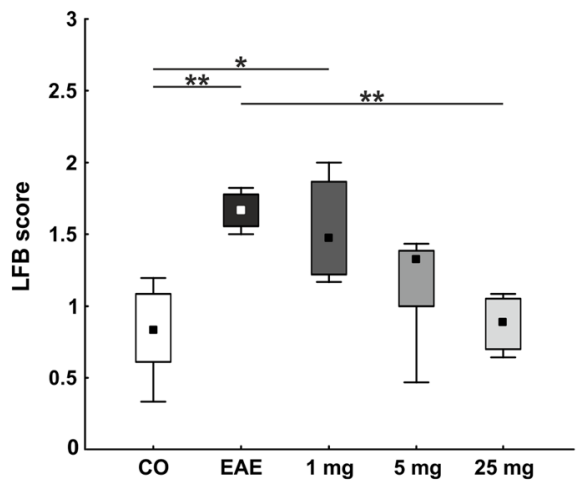

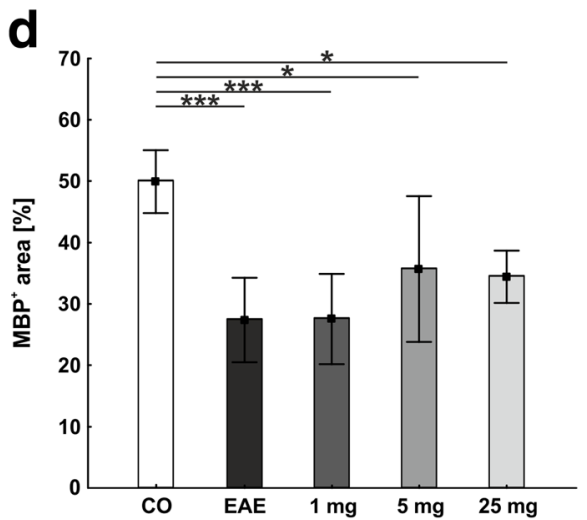

Fig. 2 Structural preservation of the optic nerve in laquinimod-treated mice. a HE-stained healthy optic nerves show a linear formation of nuclei in a bead-like manner (green arrow), which in EAE is disrupted (white arrows) and might comprise cellular conglomerates (orange arrowheads). The usual structure of LFB-stained myelin sheaths in optic nerve tissue resembles combed bundles in a steady parallel arrangement (control group). In EAE, brightening in structure represents an interruption of this arrangement (star). Labeling of MBP, a main component of myelin sheaths, shows specific changes in myelin structure. b Cellular infiltration measured via HE score. c Demyelination measured via LFB score. $\mathbf{d}$ Demyelination measured via MBP staining. Values represent median, interquartile range, range in $\mathbf{b}$ and $\mathbf{c}$, and mean $\pm \mathrm{SD}$ in $\mathbf{d}$. Kruskal-Wallis plus Dunn's test for $\mathbf{b}$ and $\mathbf{c}$ and one-way ANOVA plus Tukey post hoc for $\mathbf{d} . N=6-7 /$ group. ${ }^{*} p<0.05,{ }^{* *} p<0.01,{ }^{* * *} p<0.001$. Scale bars: $40 \mu \mathrm{m}$ in HE and LFB, $20 \mu \mathrm{m}$ in MBP

versus $40.8 \pm 23.9$ cells $/ \mathrm{mm}^{2} ; p<0.001$ ). Treatment with 5 and $25 \mathrm{mg} / \mathrm{kg}$ laquinimod significantly reduced the numbers of $\mathrm{Tmem}^{-}$and $\mathrm{Iba1}^{+}$cells compared to EAE ( $5 \mathrm{mg} / \mathrm{kg}: 128.9 \pm 66.3$ cells $/ \mathrm{mm}^{2}, p=0.007 ; 25 \mathrm{mg} / \mathrm{kg}$ : $64.5 \pm 44.5$ cells $\left./ \mathrm{mm}^{2}, p<0.001\right)$. The $1 \mathrm{mg} / \mathrm{kg}$ laquinimod group showed no significant effect $\left(208.3 \pm 71.6\right.$ cells $/ \mathrm{mm}^{2}$, $p>0.05$ ).

The co-staining of Iba1 with an F4/80 antibody was used to select cells with macrophage function (Fig. 3e). The EAE group expressed significantly more $\mathrm{F} 4 / 80^{+}$and 

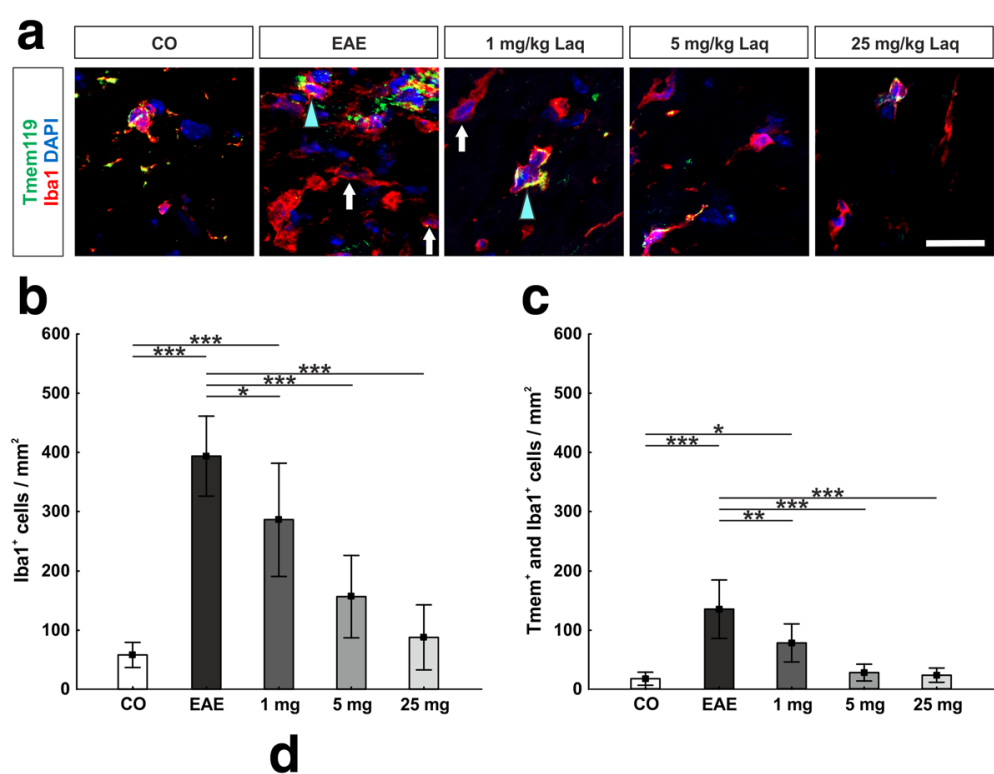

c
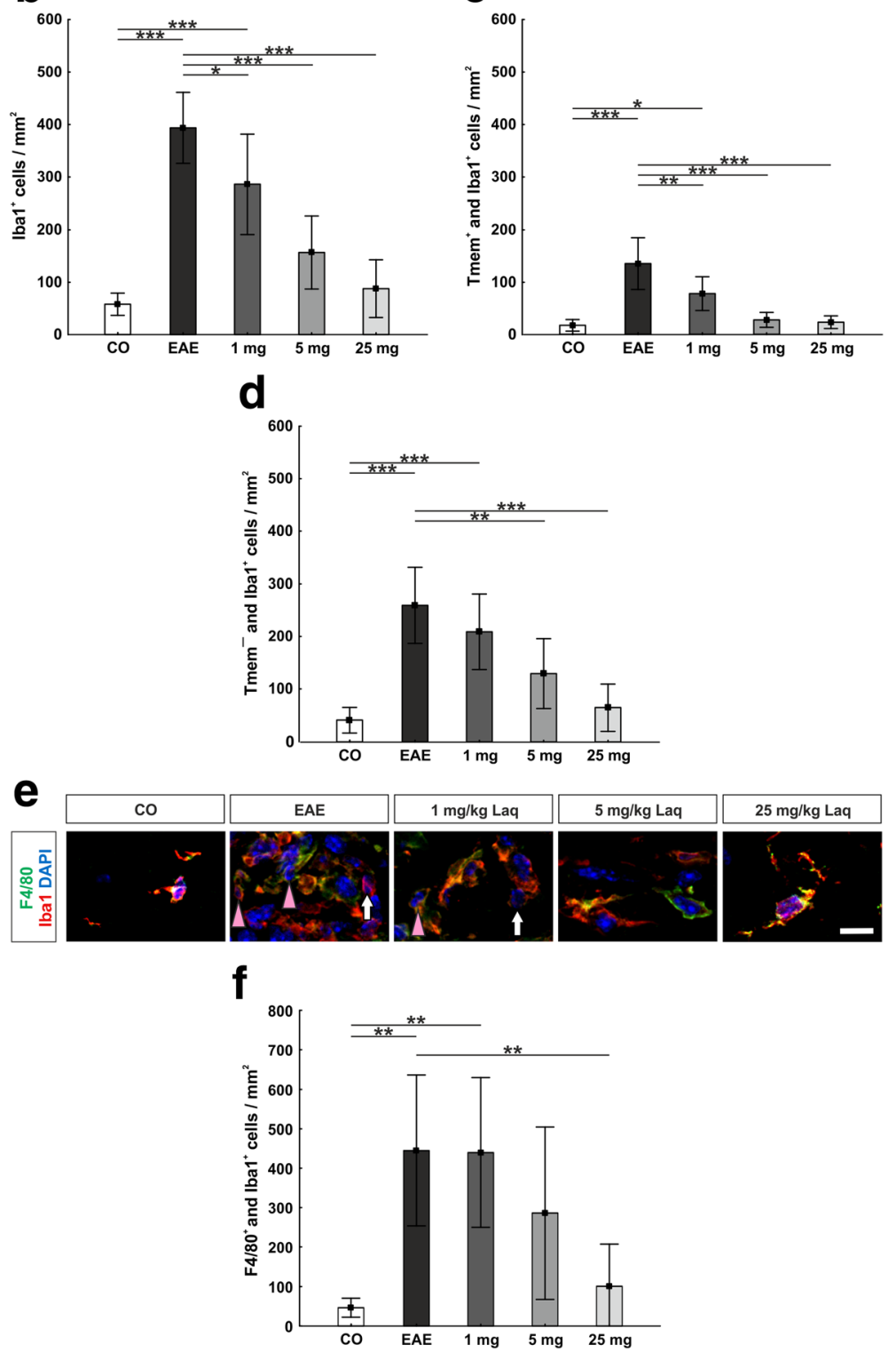

Fig. 3 Less microglia and recruited phagocytes in the optic nerve under laquinimod treatment. a Iba1 antibody was used to label all phagocytes and combined with Tmem119 antibody to distinguish between microglia ( $\mathrm{Tmem}^{+}$and $\mathrm{Iba} 1^{+}$, turquoise arrowheads) and recruited phagocytes (Tmem ${ }^{-}$and $\mathrm{Iba}^{+}{ }^{+}$, white arrows). b Numbers of phagocytes $/ \mathrm{mm}^{2}$. c Numbers of microglia $/ \mathrm{mm}^{2}$. d Numbers of infiltrating phagocytes $/ \mathrm{mm}^{2}$. All groups showed more infiltrating phagocytes than microglia. e Iba1 and F4/80 antibody to select cells with macrophage function (F4/80 and $\mathrm{Iba}^{+}{ }^{+}$, pink arrowheads). $\mathbf{f}$ Numbers of cells with macrophage function $/ \mathrm{mm}^{2}$. Values represent mean $\pm \mathrm{SD}$. One-way ANOVA and Tukey post hoc. $N=6-7 /$ group. ${ }^{*} p<0.05,{ }^{* *} p<0.01,{ }^{* * *} p<0.001$. Scale bars: $20 \mu \mathrm{m}$ in $\mathbf{a}, 10 \mu \mathrm{m}$ in $\mathbf{e}$ 
Iba1 $^{+}$cells than the control group $(444.6 \pm 191.2$ cells/ $\mathrm{mm}^{2}$ versus $46.4 \pm 24.1$ cells $/ \mathrm{mm}^{2} ; p=0.002$ ) (Fig. 3f). Under application of $25 \mathrm{mg} / \mathrm{kg}$ laquinimod, significantly diminished numbers of $\mathrm{F} 4 / 80^{+}$and $\mathrm{Iba}^{+}$cells $(100.8 \pm$ 106.4 cells $/ \mathrm{mm}^{2}, p<0.01$ ) were detected compared to EAE mice, whereas lower doses showed no significant changes $\left(1 \mathrm{mg} / \mathrm{kg}: 439.5 \pm 189.8 \mathrm{cells} / \mathrm{mm}^{2} ; 5 \mathrm{mg} / \mathrm{kg}\right.$ : $286.0 \pm 218.6$ cells $/ \mathrm{mm}^{2}$; both $p>0.05$ ).

\section{Laquinimod did not affect macroglia in the optic nerve} Macroglial cells were detected by labeling with a GFAP antibody (Fig. 4a). No significant changes in the GFAP ${ }^{+}$ area were found in mice treated with laquinimod compared to the EAE group (all $p>0.05$; EAE: $21.4 \pm 3.1 \% /$ image; $1 \mathrm{mg} / \mathrm{kg}: 22.3 \pm 5.0 \% /$ image; $5 \mathrm{mg} / \mathrm{kg}: 24.9 \pm$ $8.5 \% /$ image; $25 \mathrm{mg} / \mathrm{kg}: 25.1 \pm 3.4 \% /$ image, control group: $14.0 \pm 5.6 \%$ /image; Fig. 4 b).

\section{Laquinimod reduced apoptosis and loss of retinal ganglion cells}

We used a Brn-3a antibody to mark retinal ganglion cells. Cleaved caspase 3 antibody was utilized to label apoptotic cells, and apoptotic retinal ganglion cells were positive for both markers (Fig. 5a). Additionally, Brn-3a mRNA expression was quantified via qRT-PCR. Compared to the control group, significantly less retinal ganglion cells were detected in EAE animals $(64.9 \pm 7.3$ cells $/ \mathrm{mm}$ versus $44.3 \pm 10.9$ cells $/ \mathrm{mm}, p<0.001$; Fig. $5 \mathrm{~b}$ ). Under administration of $5 \mathrm{mg} / \mathrm{kg}$ laquinimod $(65.9 \pm$ 5.2 cells $/ \mathrm{mm}, p<0.001$ ) and $25 \mathrm{mg} / \mathrm{kg}$ laquinimod $(64.2 \pm 4.6$ cells $/ \mathrm{mm}, \quad p<0.001)$, significantly higher numbers of retinal ganglion cells could be observed compared to the EAE group. For the group receiving $1 \mathrm{mg} / \mathrm{kg}$ laquinimod, no significant difference could be shown $(47.8 \pm 4.9$ cells $/ \mathrm{mm}, p=0.886)$. In line with the results of Brn-3a immunostaining, qRT-PCR analyses displayed a significantly lower Brn-3a mRNA expression in EAE animals (0.62-fold expression) compared to the control group $(p=0.036$; Fig. 5 d; Additional file 1). Under the dose of $25 \mathrm{mg} / \mathrm{kg}$ laquinimod, the trend of an increased Brn-3a mRNA expression compared to the EAE group was noted (1.56-fold, $p=0.074$; Fig. 5e; Additional file 1).

The percentage of apoptotic retinal ganglion cells from all retinal ganglion cells displayed a non-significant trend of higher fractions in the EAE group $(54.4 \pm 7.6 \%)$ compared to the control group $(35.5 \pm 6.1 \%, p=0.051$; Fig. 5c). Administration of laquinimod in doses of 5 $(29.5 \pm 16.0 \%, p=0.006)$ and $25 \mathrm{mg} / \mathrm{kg}(33.9 \pm 10.1 \%$, $p=0.029)$ led to a significant reduction in the percentage of apoptotic retinal ganglion cells compared to EAE animals. Again, application of $1 \mathrm{mg} / \mathrm{kg}$ laquinimod showed no significant effect $(50.8 \pm 13.5 \%, p=0.972)$.

\section{Less retinal microglia and macrophages under laquinimod treatment}

Similar to the optic nerve, we focused on retinal microglia via Tmem119 (overview staining, Fig. 6a). Retinal phagocytes were detected via Iba1 (Fig. 6a, b) and co-stained with the macrophage marker anti-F4/80 (Fig. 6b).

In EAE animals, significantly more $\mathrm{Iba1}^{+}$phagocytes were counted than in the control group $(17.3 \pm 3.8$ cells $/ \mathrm{mm}$
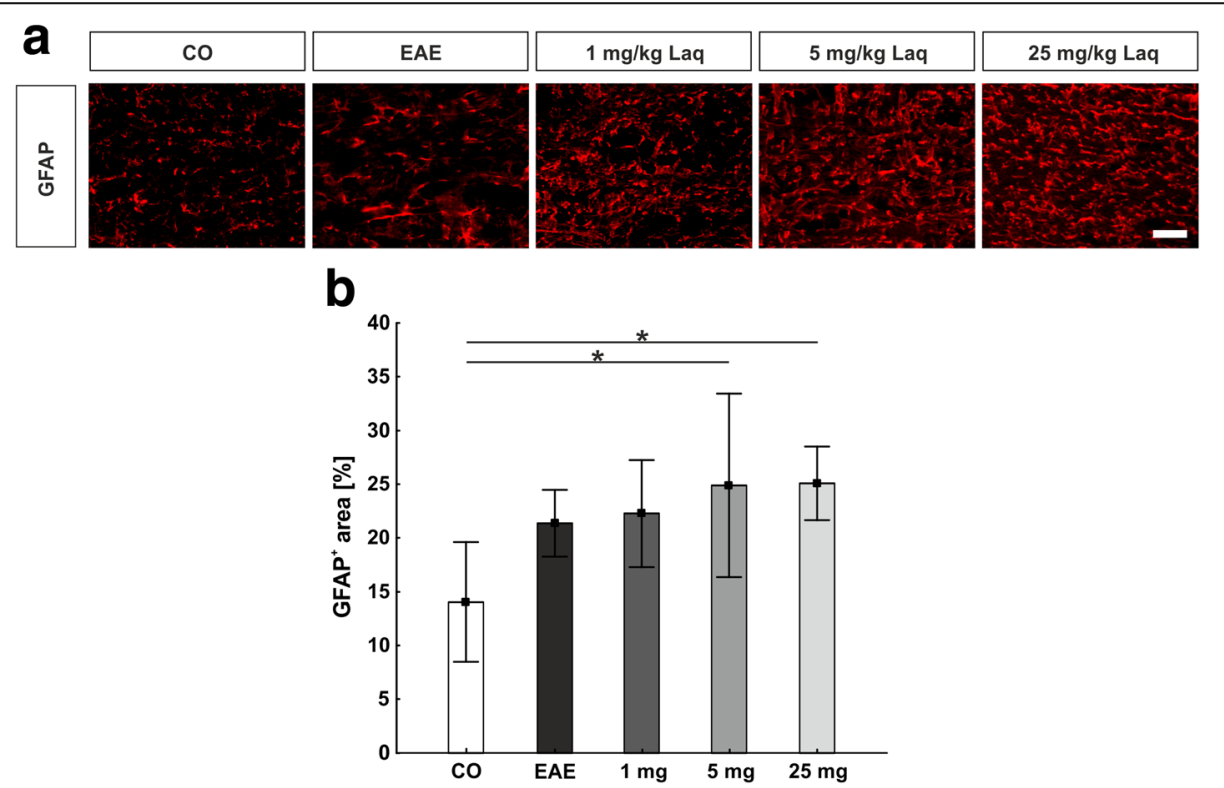

Fig. 4 No change of macroglia in the optic nerve under laquinimod treatment. a Macroglia were labeled with GFAP antibody. b Macroglia signal area as percentage. Values represent mean \pm SD. One-way ANOVA plus Tukey post hoc. $N=6-7 /$ group. ${ }^{*} p<0.05$. Scale bar: $20 \mu \mathrm{m}$ 


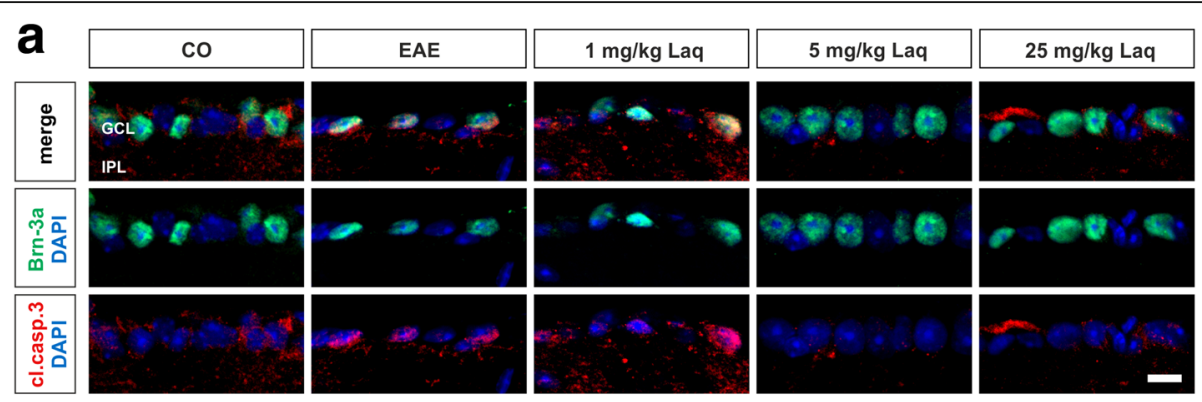

b

\section{C}
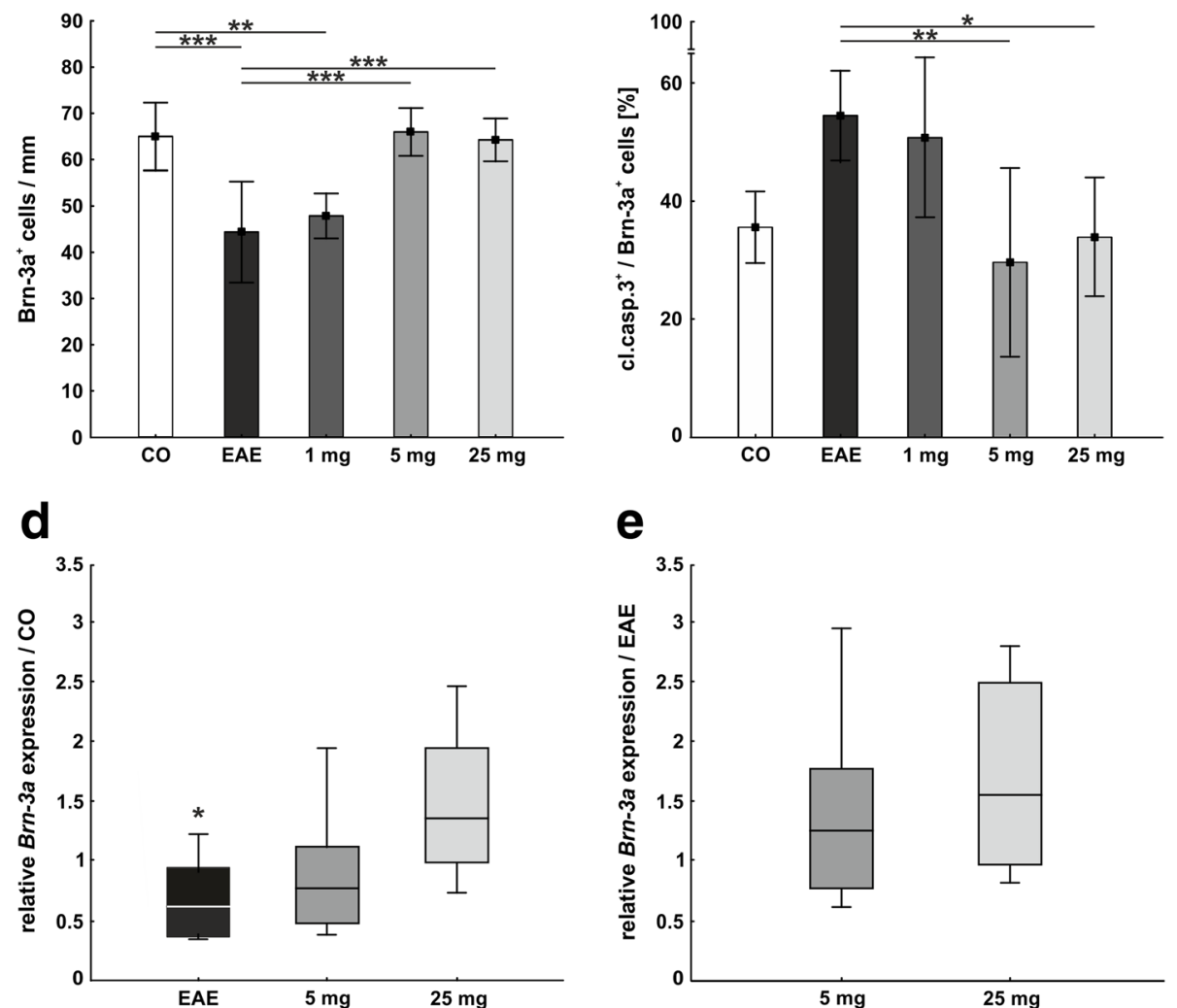

Fig. 5 Protection of retinal ganglion cells under laquinimod treatment. a Retinal ganglion cells were marked with Brn-3a antibody (green), apoptotic cells via cleaved caspase 3 antibody (red). b Numbers of retinal ganglion cells $/ \mathrm{mm}$. c Percentage of apoptotic retinal ganglion cells. $\mathbf{d}$ Brn-3a expression compared to the control group. e Brn-3a expression compared to the EAE group. Values represent mean \pm SD in $\mathbf{b}$ and $\mathbf{c}$ and median, interquartile range, range in $\mathbf{d}$ and $\mathbf{e}$. One-way ANOVA plus Tukey post hoc for $\mathbf{b}$ and $\mathbf{c}$ and pairwise fixed reallocation and randomization test for d and e. $N=6-7 /$ group in a-c and $n=5 /$ group in $\mathbf{d}$ and $\mathbf{e} .{ }^{*} p<0.01,{ }^{* *} p<0.01,{ }^{* * *} p<0.001$. Scale bar: $10 \mu \mathrm{m}$. GCL = ganglion cell layer, IPL $=$ inner plexiform layer

versus $3.9 \pm 0.8$ cells $/ \mathrm{mm} ; p<0.001$ ) (Fig. 6c). Laquinimod in doses of $5 \mathrm{mg} / \mathrm{kg}(6.5 \pm 3.4$ cells $/ \mathrm{mm}, p<0.001)$ and $25 \mathrm{mg} / \mathrm{kg} \quad(5.1 \pm 1.3$ cells $/ \mathrm{mm}, \quad p<0.001)$ significantly reduced the number of phagocytes compared to EAE animals. The lowest laquinimod dose had no detectable impact $(1 \mathrm{mg} / \mathrm{kg}: 13.9 \pm 3.7$ cells $/ \mathrm{mm}, p=0.223)$.

$\mathrm{Co}$-staining of F4/80 and Iba1 revealed significantly more $\mathrm{F} 4 / 80^{+}$and $\mathrm{Iba}^{+}$cells in the EAE group than in the control group $(15.7 \pm 3.6$ cells $/ \mathrm{mm}$ versus $3.1 \pm 1.0$ cells $/ \mathrm{mm}$; $p<0.001$; Fig. 6d). Under application of 5 and $25 \mathrm{mg}$ laquinimod $/ \mathrm{kg}$, significantly diminished numbers of macrophages were detected than in the EAE group ( $5 \mathrm{mg} / \mathrm{kg}: 5.0 \pm 2.9$ cells $/ \mathrm{mm}, 25 \mathrm{mg} / \mathrm{kg}: 4.2 \pm 0.9$ cells/ $\mathrm{mm}$; both $p<0.001)$. The lowest dose showed no significant difference $(1 \mathrm{mg} / \mathrm{kg}: 12.6 \pm 3.3$ cells $/ \mathrm{mm}, p=0.227)$.

Moreover, retinal Iba1, Tmem119 (microglia), AMWAP (activated microglia), and CD68 (macrophages) mRNA expression was analyzed via qRT-PCR (Fig. 6e-l, Additional file 1). Iba1 mRNA expression analysis corroborated the results of the Iba1-immunostaining. Not only the EAE group, but also animals receiving $5 \mathrm{mg} / \mathrm{kg}$ laquinimod showed significantly higher expressions of $I b a 1$ mRNA 


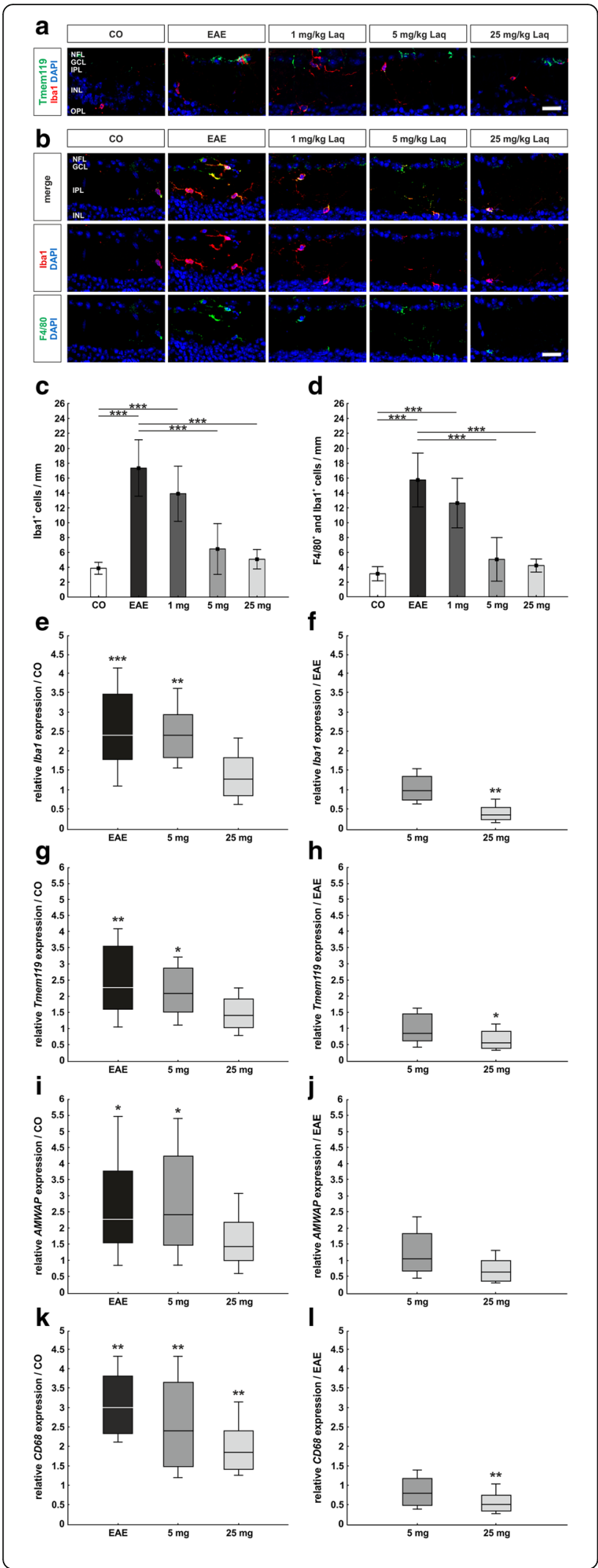

Fig. 6 Less retinal microglia and macrophages under laquinimod treatment. a Exemplary staining of retinal Tmem119 (microglia) and Iba1 (phagocytes). b lba 1 antibody (red) and F4/80 antibody (green) were co-stained to select cells with macrophage function. c Numbers of phagocytes/mm. d Numbers of cells with macrophage function/ $\mathrm{mm}$. e $\mid \mathrm{bal}$ expression compared to the control group. $\mathbf{f} \mid \mathrm{ba} \mathbf{l}$ expression compared to the EAE group. $\mathbf{g}$ Tmem 119 expression compared to control. $\mathbf{h}$ Tmem 119 expression compared to EAE. $\mathbf{i}$ Expression of active microglia marker AMWAP compared to the control group. $\mathbf{j}$ AMWAP expression compared to EAE. $\mathbf{k}$ Macrophage marker CD68 expression compared to the control group. I CD68 expression compared to EAE. Values represent mean \pm SD in $\mathbf{c}$ and $\mathbf{d}$ and median, interquartile range, range in $\mathbf{e}-$ I. One-way ANOVA plus Tukey post hoc for $\mathbf{c}$ and $\mathbf{d}$; pairwise fixed reallocation and randomization test for $\mathbf{e}-\mathbf{I}$. $N=6-7 /$ group in $\mathbf{b}-\mathbf{d}$ and $n=5 /$ group in $\mathbf{e}-\mathbf{l}$. ${ }^{*} p<0.01$, ${ }^{* *} p<0.01$,

${ }^{* * *} p<0.001$. Scale bars: $20 \mu \mathrm{m}$. NFL = nerve fiber layer, $\mathrm{GCL}=$ ganglion cell layer, IPL = inner plexiform layer, $\mathrm{INL}=$ inner nuclear layer, $\mathrm{OPL}=$ outer plexiform layer

than control animals (EAE: 2.41 -fold, $p<0.001 ; 5 \mathrm{mg} / \mathrm{kg}$ : 2.42-fold, $p=0.002$; Fig. 6e; Additional file 1). A significantly lower $I b a 1$ mRNA expression than in EAE mice was only observed under application of $25 \mathrm{mg} / \mathrm{kg}$ laquinimod (0.38-fold, $p=0.003$; Fig. 6f; Additional file 1).

Expression analyses of the microglia marker Tmem119 showed a significantly higher expression of Tmem119 mRNA in the EAE group and the $5 \mathrm{mg} / \mathrm{kg}$ laquinimod group compared to the control group (EAE: 2.27-fold, $p=0.006 ; 5 \mathrm{mg} / \mathrm{kg}$ : 2.11-fold, $p=0.01 ;$ Fig. 6; Additional file 1). Application of $25 \mathrm{mg} / \mathrm{kg}$ laquinimod significantly reduced Tmem119 mRNA expression compared to EAE mice (0.57-fold, $p=0.038$; Fig. 6h; Additional file 1).

The expression of $A M W A P$, a marker for active microglia [36], which rises in different models of retinal pathologies $[37,38]$ was increased in both EAE and $5 \mathrm{mg} / \mathrm{kg}$ laquinimod animals (EAE: 2.27-fold, $p=0.024 ; 5 \mathrm{mg} / \mathrm{kg}$ : 2.45-fold, $p=0.017$; Fig. 6i; Additional file 1). Under therapy with $25 \mathrm{mg} / \mathrm{kg}$ laquinimod, a trend of diminished AMWAP mRNA expression compared to EAE mice was seen (0.64-fold, $p=0.06$; Fig. 6j; Additional file 1).

In qRT-PCR expression analyses of the macrophage marker $C D 68$, a significantly higher expression of $C D 68$ mRNA compared to the control group was not only found in the EAE group (3.01-fold, $p=0.002$; Fig. 6k; Additional file 1), but also in the groups receiving $5 \mathrm{mg} / \mathrm{kg}$ laquinimod (2.41-fold, $p=0.002)$ and $25 \mathrm{mg} / \mathrm{kg}$ laquini$\bmod (1.85$-fold, $p=0.003)$. Animals treated with $25 \mathrm{mg} / \mathrm{kg}$ laquinimod expressed significantly less retinal CD68 mRNA than the EAE group (0.53-fold, $p=0.008$; Fig. 6l; Additional file 1).

\section{Diminished retinal macroglia response under application of laquinimod}

Retinal macroglia were detected via GFAP and vimentin (Fig. 7a). Moreover, retinal GFAP mRNA expression was analyzed via qRT-PCR (Additional file 1). 

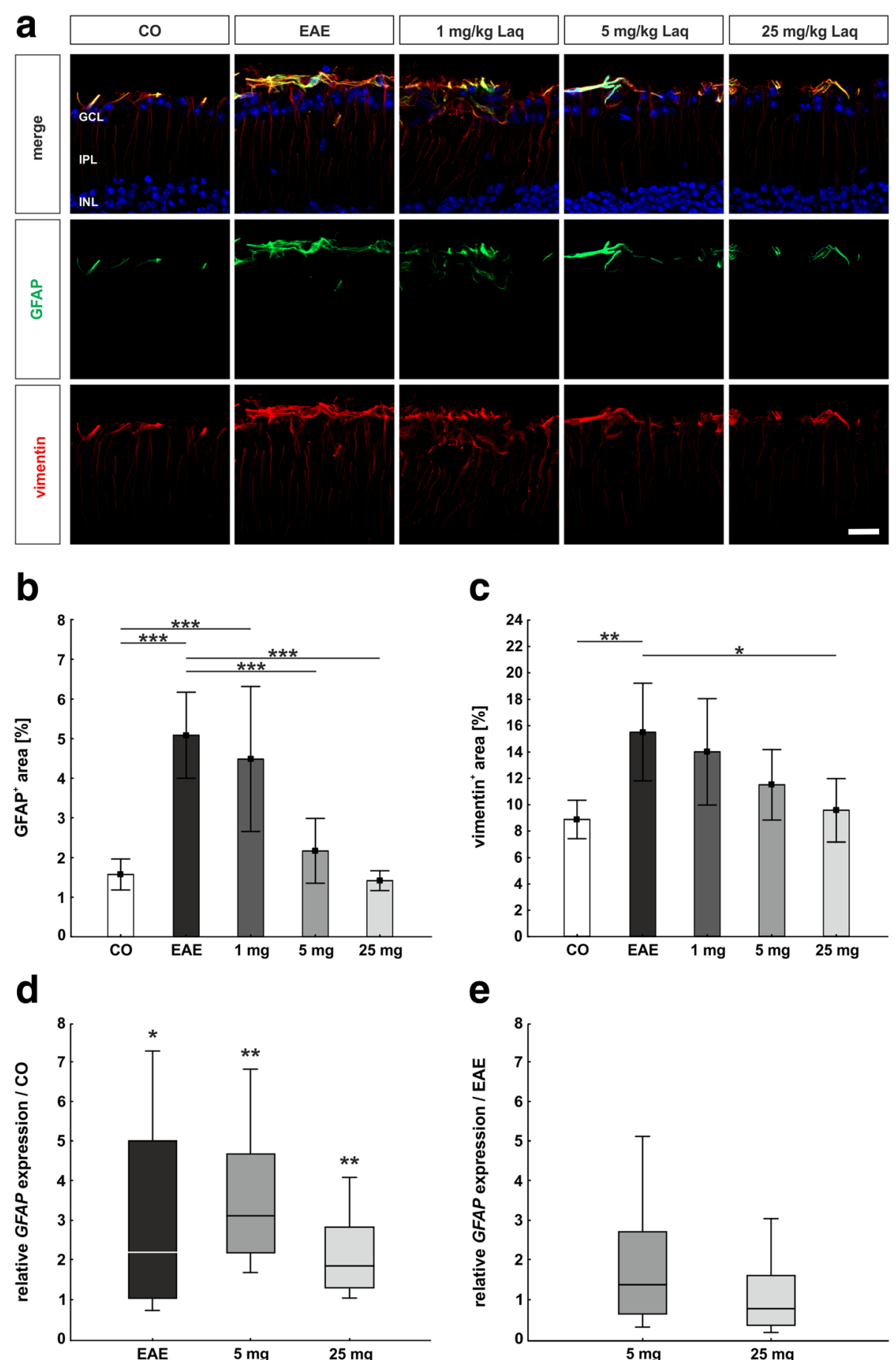

Fig. 7 Less retinal macroglia response under laquinimod treatment. a GFAP antibody was applied to mark retinal macroglia (green). Retinal Müller glia was investigated via vimentin antibody (red). b Macroglia signal area as percentage. c Müller glia signal area as percentage. d GFAP expression compared to the control group. e GFAP expression compared to EAE. Values represent mean \pm SD in $\mathbf{b}$ and $\mathbf{c}$ and median, interquartile range, range in $\mathbf{d}$ and $\mathbf{e}$. One-way ANOVA plus Tukey post hoc for $\mathbf{b}$ and $\mathbf{c}$; pairwise fixed reallocation and randomization test for $\mathbf{d}$ and $\mathbf{e} . \mathrm{N}=6-7 / \mathrm{group}$ in $\mathbf{a}-\mathbf{c}$ and $n=5 /$ group in $\mathbf{d}$ and $\mathbf{e} .{ }^{*} p<0.05,{ }^{* *} p<0.01,{ }^{* * *} p<0.001$. Scale bars: $20 \mu \mathrm{m}$. GCL = ganglion cell layer, IPL = inner plexiform layer, INL $=$ inner nuclear layer

The EAE group showed a significantly larger $\mathrm{GFAP}^{+}$ macroglial signal area than the control group $(5.1 \pm$ $1.1 \% /$ image versus $1.6 \pm 0.4 \% /$ image; $p<0.001$; Fig. $7 b$ ).
In the groups receiving $5 \mathrm{mg} / \mathrm{kg}$ laquinimod $(2.2 \pm 0.8 \% /$ image, $p<0.001)$ and $25 \mathrm{mg} / \mathrm{kg}$ laquinimod $(1.4 \pm 0.3 \% /$ image, $p<0.001)$, significantly less $\mathrm{GFAP}^{+}$signal area 
was observed than in the EAE group. The group receiving $1 \mathrm{mg} / \mathrm{kg}$ laquinimod showed no significant difference compared to the EAE group $(4.5 \pm 1.8 \% /$ image, $p=$ $0.833)$. The qRT-PCR analysis revealed significantly more GFAP mRNA in the EAE group (2.23-fold, $p=0.03$; Fig. $7 \mathrm{~d}$; Additional file 1) compared to the control group. Also in the groups receiving laquinimod, a higher GFAP mRNA expression than in the control group was detected $(5 \mathrm{mg} / \mathrm{kg}$ : 3.13 -fold, $p=0.003 ; 25 \mathrm{mg} / \mathrm{kg}$ : 1.88 -fold, $p=0.006$; Fig. 7d; Additional file 1). Compared to the EAE group, no significant changes in GFAP mRNA expression were noted for treated mice $(5 \mathrm{mg} / \mathrm{kg}$ : $1.40-$ fold, $p=0.4 ; 25 \mathrm{mg} / \mathrm{kg}$ : 0.84-fold, $p=0.6$; Fig. 7e; Additional file 1).

We used a vimentin antibody to examine Müller glia in retinal tissue (Fig. 7a). The EAE group showed significantly more vimentin ${ }^{+}$Müller glia signal area than the control group ( $15.5 \pm 3.7 \%$ /image versus $8.9 \pm 1.5 \% /$ image; $p=0.007$ ) (Fig. 7c). Application of laquinimod in the dose of $25 \mathrm{mg} / \mathrm{kg}$ significantly decreased the area of vimentin signal $(9.6 \pm 2.4 \% /$ image, $p=0.019)$ in comparison to the EAE group. Smaller doses of laquinimod caused slight but non-significant reduction of Müller glia signal ( $1 \mathrm{mg}$ : $14.0 \pm 4.0 \% /$ image; $5 \mathrm{mg}$ : $11.5 \pm 2.7 \%$ /image; both $p>0.05$ ).

\section{Later therapeutic treatment led to a decreased EAE score and preservation of retinal function}

To investigate the effect of a delayed therapy, EAE animals received laquinimod $(25 \mathrm{mg} / \mathrm{kg}$ ) from day $16 \mathrm{on}$, since $60 \%$ of the animals had developed clinical signs by then. Laquinimod treatment led to a decreased EAE score (Fig. 8a). From day 28 to 30, the EAE score of the treated group was significantly lower than in the EAE group $(p=0.04)$.

ERG measurements, at the flash intensity of $10 \mathrm{~cd} . \mathrm{s} / \mathrm{m}^{2}$, revealed no changes in the a-wave amplitude between EAE and laquinimod-treated animals $(p=0.2)$ (Fig. 8b). However, the $25 \mathrm{mg} / \mathrm{kg}$ laquinimod group displayed a
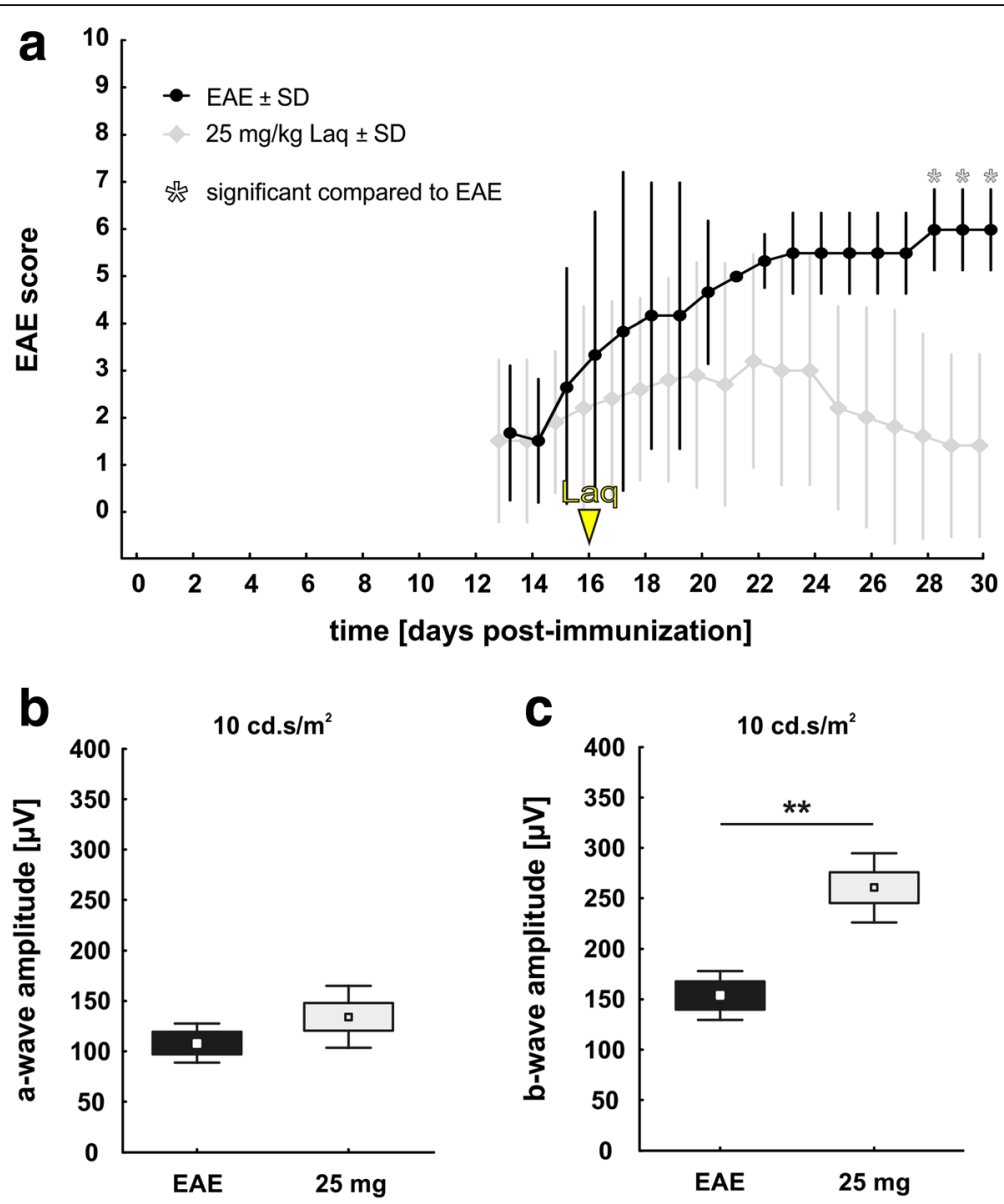

Fig. 8 Clinical effects of therapeutic laquinimod treatment. a Mean clinical EAE scores after immunization with MOG $_{35-55}$ peptide. Yellow arrowhead: start of laquinimod treatment. $\mathbf{b}$ Electroretinograms were measured at day 30 . A-wave amplitudes illustrate conductivity of photoreceptors. c B-wave amplitudes illustrate conductivity of the inner nuclear layer. Values represent mean \pm SD in $\mathbf{a}$, mean $\pm S D \pm S E M$ in $\mathbf{b}$ and $\mathbf{c}$. Mann-Whitney $U$ test for $\mathbf{a}$; Student's $t$ test for $\mathbf{b}$ and $\mathbf{c} . N=3-5 /$ group in $\mathbf{a}-\mathbf{c} .{ }^{*} p<0.05,{ }^{* *} p<0.01$ 
significantly improved b-wave amplitude compared to the EAE group at a flash intensity of $10 \mathrm{~cd} \mathrm{~s} / \mathrm{m}^{2}(p=0.003)$ (Fig. 8c).

To evaluate the effects of a delayed therapy on optic nerves, sections were stained with HE and LFB (Fig. 9a)

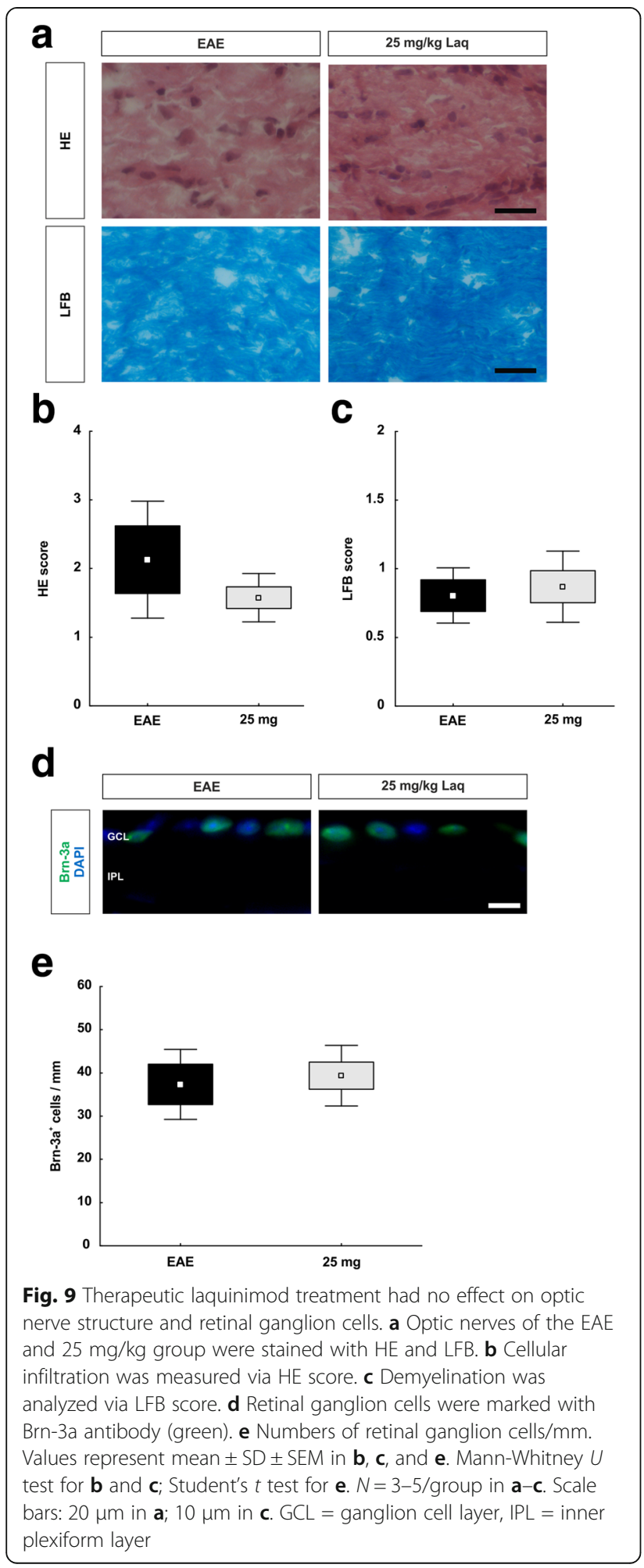

and scored. Regarding the HE score, no distinct differences were observed between the treatment group $(1.58 \pm 0.16)$ and the EAE animals $(2.13 \pm 0.49 ; p=0.55)$ (Fig. 9b). Additionally, LFB staining did not reveal any differences between optic nerves of treated mice and those of the EAE group $(25 \mathrm{mg} / \mathrm{kg}$ : $0.87 \pm 0.12$; EAE: $0.81 \pm 0.12 ; p=1.0$ ) (Fig. 9c). Demyelination was comparable in both groups.

Retinal ganglion cells were labeled with a Brn-3a antibody (Fig. 9d). We observed no alteration in the number of Brn- $3 \mathrm{a}^{+}$cells in treated animals $(39.39 \pm 3.14$ cells $/ \mathrm{mm})$ in comparison to retinas of the EAE group $(37.37 \pm 4.68$ cells $/ \mathrm{mm} ; p=0.7$ ) (Fig. 9e). Loss of retinal ganglion cells occurred equally in both groups.

\section{Discussion}

We investigated potential effects of laquinimod on the visual system in $\mathrm{MOG}_{35-55}$-immunized EAE mice. We found that laquinimod treatment protected optic nerves from EAE typical immune cell infiltration and demyelination. It reduced microglia and macrophages in both retina and optic nerve and decreased retinal macroglia. Moreover, it rescued retinal ganglion cells from apoptosis and conserved the electrical output of the inner nuclear layer. Delayed treatment improved clinical signs and partly retinal function.

\section{Reduced autoimmune response in optic nerve and retina} In EAE, microglial activation, phagocyte infiltration, and T-cellular influx are assumed to generate inflammatory lesions which are linked with demyelination and axonal injury in the spinal cords, brains [13], and optic nerves [17] of immunized animals.

Measurements in human MS lesions revealed six to 12 times higher numbers of macrophages than T cells [39]. Additionally, in the course of EAE microglia and macrophage levels remain higher than T-lymphocyte levels, the latter decreasing after an initial peak [40]. These findings indicate a major role of microglia and macrophages in MS. Consequently, the focus of our work lies on microglia and recruited phagocytes, as T-cell responses have already been monitored under laquinimod therapy in several studies [41-44].

Microglia have adverse functions: in a regular balance, they monitor the CNS $[45,46]$ and remove cellular detritus [47], whereas in EAE they fuel inflammation and neurotoxic processes [17, 48-51]. MS patients without activated microglia in their lesions show better outcomes of disease [52, 53]. In our study, we differentiated between resting microglia and infiltrating macrophages $[35,54,55]$. Administration of laquinimod led to reduced numbers of microglia in both optic nerve and retina. This correlates with findings by Mishra et al. in spinal cords of EAE mice, where laquinimod diminished numbers and activation of microglia [56]. The authors 
discuss the underlying mode of action to be a preservation of miR124a and interference with several signaling pathways for microglial activation. Yet, active microglia were increased in EAE, but not reduced under therapy in our findings.

Recruited phagocytes formed a remarkably larger proportion than microglia in our model, in which we explanted optic nerves and eyes in the beginning chronic phase of EAE. This matches observations that in the course of lesion development in MS, a shift from resident microglia to recruited, blood-derived macrophages takes place [55]. Laquinimod diminished numbers of recruited phagocytes.

\section{Preservation of optic nerve structures}

Tissue infiltration with inflammatory cells causing demyelination was observed in the optic nerve in several EAE studies before $[14,15,29]$. In our study, we detected a reduced degree of cellular infiltration, especially recruited phagocytes, under laquinimod therapy.

Nevertheless, also T cells can be part of the inflammatory infiltrates in the context of autoimmune disorders $[13,16]$. Laquinimod regulates T-cellular cytokine levels in favor of the anti-inflammatory $\mathrm{T}_{\mathrm{H}} 2$ and $\mathrm{T}_{\mathrm{H}} 3$ subtype [43] and downregulates pro-inflammatory $\mathrm{T}_{\mathrm{H}} 1$ cytokines, especially interferon (IFN) $-\gamma$ and tumor necrosis factor (TNF) $-\alpha$ [42].

The infiltration with inflammatory cells is linked with demyelination in EAE optic nerves [15]. A protective effect of laquinimod on myelin sheaths was observed in our assessment. A negative correlation between axonal integrity and the number of microglia/macrophages can be found [56]. Thöne et al. suggest an upregulation of brain-derived neurotrophic factor to be the underlying myelin-protective mode of action in laquinimod [57]. Generally, the extent of demyelination to a certain degree depends on the type of EAE model that is applied: MOG-induced EAE lesions in mice display a high degree of global tissue injury, whereas the extent of primary demyelination is far lower [13]. Moreover, particularly, in C57BL/6 mice, $\mathrm{MOG}_{35-55}$ immunization does not cover auto-antibody-triggered destruction of myelin sheaths [13]. Therefore, our results on cellular infiltration in the optic nerve might be more conclusive than the degree of demyelination we measured. A delayed onset of treatment did not preserve the structure of the optic nerves. We assume that the inflammation-induced damage was already too severe. Our findings concerning the impact of laquinimod on optic nerve structures are congruent with investigations on mice brains in EAE, in which laquinimod was already shown to reduce both inflammatory infiltration and demyelination $[58,59]$.

\section{Reduced retinal macroglia response}

Regarding macroglia, we focused on astrocytes. In CNS injuries, astrocytes can leave their normal state and become reactive forming a glial scar [60-62]. Thus, astrocytes can display dichotomic effects as reviewed for MS by Correale et al.: recruitment of immune cells, secretion of cytotoxic factors and inhibition of remyelination and axonal regeneration are opposed to modulation of the blood brain barrier integrity, improved viability of neurons, and induction of remyelination [61]. In a chronic $\mathrm{MOG}_{35-55}$ EAE model in C57/BL6 mice, the point in time of disease was shown to be of vital importance for the role of astrocytes: in the acute phase of EAE (days 0 to 15 post-immunization), depletion of reactive astrocytes aggravated clinical symptoms, whereas in the chronic phase (days 30 to 50) absence of reactive astrocytes reduced EAE scores [63]. From this, a negative impact of reactive gliosis in late EAE can be deduced. Performing explants in the beginning chronic phase, we observed that administration of laquinimod decreased retinal macroglia signals and therefore seemed to reduce EAE-induced reactive gliosis in the retina, but not in the optic nerve. Earlier experiments have shown difficulties in the quantification of macroglia signal in the optic nerve, as strong structural degeneration in EAE impedes area analyses [17].

In cuprizone-induced CNS demyelination, the effect of laquinimod on astrocytes was reported as a reduction of NF- $\mathrm{kB}$ activation in astrocytes and a diminished production of astrocytic pro-inflammatory cytokines [64]. The decreasing counts of retinal microglia we observed may also be a direct effect of astrocyte reduction, as less microglial infiltration was found in the retinas of GFAP and vimentin knockout mice [65].

\section{Protection of retinal ganglion cells and preserved conductivity of the inner nuclear layer}

Retinal ganglion cell loss is common in $\operatorname{EAE}[15,17,47,66]$. The underlying mechanism is bilaterally discussed: most studies postulate that retinal ganglion cell loss represents a secondary effect of optic nerve inflammation [67-69], whereas current findings from human optic coherence tomography propose a development independent of optic nerve pathologies [70]. A breakdown of the blood retina barrier might be decisive here [66], as this provides migration of inflammatory cells, such as macrophages, into the retina. In our study, administration of laquinimod was linked with preserved retinal ganglion cell numbers. This could be due to diminished retinal microglia activation and macrophage infiltration as well as reduced astrocytic NF- $\mathrm{KB}$ activation and reduced apoptotic mechanisms under laquinimod treatment. In line with that, inhibition of NF- $\mathrm{kB}$ is associated with stagnation of retinal ganglion cell death in EAE mice [71]. However, a delayed treatment did not have any effects on the number of retinal ganglion cells in the $25 \mathrm{mg} / \mathrm{kg}$ laquinimod group. Since the structure of the optic nerves could also not be preserved, it is likely that inflammation-induced damage was already irreversible. 
Next to retinal ganglion cell death, neuronal degeneration of the inner nuclear layer forms another retinal symptom in MS [72]. Accordingly, in our scotopic ERG measurements, we detected a diminished electrical output of neurons of the inner nuclear layer (INL) in EAE mice. With regard to their electrical output, neurons of the inner nuclear layer seem to be susceptible to retinal pathologies, as ERG measurements in another model of retinal degeneration, the ischemia-reperfusion model, already revealed [28]. Laquinimod nearly preserved the electrical output of the INL, which forms a retinal equivalent to the reduction of axonal optic nerve injury that could be shown. When treatment was started later, some preservation of retinal function could be observed.

\section{Influence of dosage}

Several studies illustrate that laquinimod influences EAE disease severity in a dose-dependent manner [21, 43, 73]. Congruent with the results from the Brueck group, we found the strongest effect for treatment with $25 \mathrm{mg} /$ $\mathrm{kg}$ and smaller effects with 5 and $1 \mathrm{mg} / \mathrm{kg}$. Despite its beneficial influence on EAE scores, in our further investigations, the $1 \mathrm{mg} / \mathrm{kg}$ dose had no detectable effect on markers of inflammation and neurodegeneration in the optic nerve or retina. Laquinimod is known to pass the blood brain barrier, regardless of its integrity. Yet, in EAE mice, exposure in the CNS measures only $13 \%$ of the peripheral blood concentration [73], which explains the need of relatively high doses. Remarkably, $5 \mathrm{mg} / \mathrm{kg}$ laquinimod achieved better results concerning the decrease of retinal ganglion cell apoptosis rates and conductivity of retinal INL than $25 \mathrm{mg} / \mathrm{kg}$ did. Whether this suggests bivalent, maybe cytotoxic effects of the highest dose on retinal ganglion cells and neurons of the INL requires further investigation.

\section{Conclusion}

The novel oral immunomodulatory agent laquinimod is known to exert neuroprotective and anti-inflammatory effects on the spinal cord and brain. Our study delivered evidence that these findings are transferable to the optic nerve and retina, which are affected first in MS. Doses of 5 and $25 \mathrm{mg} / \mathrm{kg}$ laquinimod attenuated MS-related pathologies in the optic nerve and retina in an EAE model. Later onset of treatment also led to some improvement of clinical signs and retinal function, but could not prevent demyelination and retinal ganglion cell loss. We were able to corroborate the positive effect of laquinimod on neurological impairment in EAE, when treatment was started early enough. As the agent showed a positive impact on the visual system, which forms a crucial spot of manifestation in MS, its neuro-ophthalmic effect might be an interesting subject of further investigations in the future.

\section{Additional file}

Additional file 1: Analyses of different mRNAs via qRT-PCR. Values are median and interquartile range. Significant differences are marked in bold. (DOCX 16.4 kb)

\begin{abstract}
Abbreviations
AMWAP: Activated microglia/macrophage whey acidic protein; CNS: Central nervous system; CO: Control group; Ct: Threshold cycle; DAPI: 4',6-Diamidino-2phenylindole; EAE: Experimental autoimmune encephalomyelitis; ERG: Electroretinogram; GCL: Ganglion cell layer; GFAP: Glial fibrillary acidic protein; HE: Hematoxylin and eosin; HSD: Honest significant difference; Iba1: Ionized calcium-binding adapter molecule 1; IFN- $\beta$ : Interferon $\beta$; IFNY: Interferon Y; INL: Inner nuclear layer; IPL: Inner plexiform layer; IQR: Interquartile range; LFB: Luxol fast blue; MBP: Myelin basic protein; miR124a: MicroRNA124a; MOG: Myelin oligodendrocyte glycoprotein; MRI: Magnetic resonance imaging; MS: Multiple sclerosis; NFL: Nerve fiber layer; NF-KB: Nuclear factor kappa-light-chain-enhancer of activated B cells; PBS: Phosphate-buffered saline; qRT-PCR: Quantitative real-time polymerase chain reaction; SD: Standard deviation; $T_{H} 1: T$ helper cell type $1 ; T_{H} 2: T$ helper cell type $2 ; T_{H} 3$ : $T$ helper cell type 3 ; Tmem119: Transmembrane protein 119; TNF-a: Tumor necrosis factor a
\end{abstract}

\section{Funding}

ATW was supported by a FoRUM (Research Funding of the Faculty of Medicine, Ruhr-University Bochum) doctoral scholarship within the structured dissertation program of the Faculty of Medicine, Ruhr-University Bochum, Germany.

\section{Authors' contributions}

ATW and SR carried out the experiments, performed the statistical analyses, drafted the manuscript, and generated graphics. SK carried out the experiments and revised the manuscript. XP, LP, IA, and GS carried out the experiments. SF, RG, and HBD revised the manuscript. SF, IK, and SCJ designed the study and drafted the manuscript. All authors read and approved the final manuscript.

Ethics approval and consent to participate Not applicable.

\section{Competing interests}

SF received travel grants from Biogen Idec and Genzyme, none related to this manuscript.

RG serves on scientific advisory boards for Teva Pharmaceutical Industries Ltd., Biogen Idec, Bayer Schering Pharma, and Novartis; has received speaker honoraria from Biogen Idec, Teva Pharmaceutical Industries Ltd., Bayer

Schering Pharma, and Novartis; serves as an editor for Therapeutic Advances in Neurological Diseases and on the editorial boards of Experimental Neurology and the Journal of Neuroimmunology; and receives research support from Teva Pharmaceutical Industries Ltd., Biogen Idec, Bayer Schering Pharma, Genzyme, Merck Serono, and Novartis, which are not related to this manuscript.

IK received honoraria for consultancy or speaking and travel reimbursement from Bayer Healthcare, Chugai, Merck, Roche, and Shire and grant support from Affectis, Biogen, Chugai and Diamed, all not related to this manuscript. The other authors declare that they have no competing interests.

\section{Publisher's Note}

Springer Nature remains neutral with regard to jurisdictional claims in published maps and institutional affiliations.

Received: 27 July 2017 Accepted: 20 May 2018

Published online: 14 June 2018

\section{References}

1. Kawachi I, Lassmann H. Neurodegeneration in multiple sclerosis and neuromyelitis optica. J Neurol Neurosurg Psychiatry. 2017;88:137-45.

2. Runia TF, van Pelt-Gravesteijn ED, Hintzen RQ. Recent gains in clinical multiple sclerosis research. CNS Neurol Disord Drug Targets. 2012;11:497-505. 
3. Olsson T, Barcellos LF, Alfredsson L. Interactions between genetic, lifestyle and environmental risk factors for multiple sclerosis. Nat Rev Neurol. 2017; 13:25-36.

4. Stadelmann C, Wegner C, Bruck W. Inflammation, demyelination, and degeneration - recent insights from MS pathology. Biochim Biophys Acta. 2011;1812:275-82.

5. Compston A, Coles A. Multiple sclerosis. Lancet. 2008;372:1502-17.

6. Gelfand JM. Multiple sclerosis: diagnosis, differential diagnosis and clinical presentation. In: Goodin DS, editor. Handbook of Clinical Neurology, vol. 122. Amsterdam: Elsevier; 2014. p. 269-90. [Aminoff MJ, Boller F, Swaab DF (Series Editor): Multiple sclerosis and related disorders].

7. Ziemssen T, Wilhelm H, Ziemssen F. Multiple sclerosis: an update with practical guidelines for ophthalmologists. Ophthalmologe. 2006;103:621-43.

8. Lampert EJ, Andorra M, Torres-Torres R, Ortiz-Perez S, Llufriu S, Sepulveda M, Sola N, Saiz A, Sanchez-Dalmau B, Villoslada P, Martinez-Lapiscina EH. Color vision impairment in multiple sclerosis points to retinal ganglion cell damage. J Neurol. 2015;262:2491-7.

9. Behbehani R. Clinical approach to optic neuropathies. Clin Ophthalmol. 2007;1:233-46

10. Sabadia SB, Nolan RC, Galetta KM, Narayana KM, Wilson JA, Calabresi PA, Frohman EM, Galetta SL, Balcer LJ. 20/40 or better visual acuity after optic neuritis: not as good as we once thought? J Neuroophthalmol. 2016:36:369-76.

11. Jenkins TM, Toosy AT. Optic neuritis: the eye as a window to the brain. Curr Opin Neurol. 2017;30:61-6.

12. Ben-Nun A, Kaushansky N, Kawakami N, Krishnamoorthy G, Berer K, Liblau R, Hohlfeld R, Wekerle H. From classic to spontaneous and humanized models of multiple sclerosis: impact on understanding pathogenesis and drug development. J Autoimmun. 2014;54:33-50.

13. Gold R, Linington C, Lassmann H. Understanding pathogenesis and therapy of multiple sclerosis via animal models: 70 years of merits and culprits in experimental autoimmune encephalomyelitis research. Brain. 2006;129:1953-71.

14. Guy J. Optic nerve degeneration in experimental autoimmune encephalomyelitis. Ophthalmic Res. 2008;40:212-6.

15. Horstmann L, Schmid H, Heinen AP, Kurschus FC, Dick HB, Joachim SC. Inflammatory demyelination induces glia alterations and ganglion cell loss in the retina of an experimental autoimmune encephalomyelitis model. J Neuroinflammation. 2013;10:120.

16. Tian AY, Zhang RW, Shi XG, Yu HM. Alteration of Thelper cell subsets in the optic nerve of experimental autoimmune encephalomyelitis. Int J Mol Med. 2010;25:869-74

17. Horstmann L, Kuehn S, Pedreiturria X, Haak K, Pfarrer C, Dick HB, Kleiter I, Joachim SC. Microglia response in retina and optic nerve in chronic experimental autoimmune encephalomyelitis. J Neuroimmunol. 2016;298:32-41.

18. Nicholas R, Giannetti P, Alsanousi A, Friede T, Muraro PA. Development of oral immunomodulatory agents in the management of multiple sclerosis. Drug Des Devel Ther. 2011;5:255-74.

19. Jansson K, Fristedt T, Olsson A, Svensson B, Jonsson S. Synthesis and reactivity of laquinimod, a quinoline-3-carboxamide: intramolecular transfer of the enol proton to a nitrogen atom as a plausible mechanism for ketene formation. J Org Chem. 2006;71:1658-67.

20. Brunmark C, Runstrom A, Ohlsson L, Sparre B, Brodin T, Astrom M, Hedlund $\mathrm{G}$. The new orally active immunoregulator laquinimod (ABR-215062) effectively inhibits development and relapses of experimental autoimmune encephalomyelitis. J Neuroimmunol. 2002;130:163-72.

21. Runstrom A, Leanderson T, Ohlsson L, Axelsson B. Inhibition of the development of chronic experimental autoimmune encephalomyelitis by laquinimod (ABR215062) in IFN-beta k.o. and wild type mice. J Neuroimmunol. 2006;173:69-78.

22. Pitarokoili K, Ambrosius B, Schrewe L, Hayardeny L, Hayden M, Gold R. Laquinimod exerts strong clinical and immunomodulatory effects in Lewis rat experimental autoimmune neuritis. J Neuroimmunol. 2014;274:38-45.

23. Comi G, Jeffery D, Kappos L, Montalban X, Boyko A, Rocca MA, Filippi M. Placebo-controlled trial of oral laquinimod for multiple sclerosis. N Engl J Med. 2012;366:1000-9.

24. Filippi M, Rocca MA, Pagani E, De Stefano N, Jeffery D, Kappos L, Montalban X, Boyko AN, Comi G. Placebo-controlled trial of oral laquinimod in multiple sclerosis: MRI evidence of an effect on brain tissue damage. J Neurol Neurosurg Psychiatry. 2014;85:851-8.

25. Vollmer TL, Sorensen PS, Selmaj K, Zipp F, Havrdova E, Cohen JA, Sasson N, Gilgun-Sherki Y, Arnold DL. A randomized placebo-controlled phase III trial of oral laquinimod for multiple sclerosis. J Neurol. 2014;261:773-83.
26. Kleiter I, Song J, Lukas D, Hasan M, Neumann B, Croxford AL, Pedre X, Hovelmeyer N, Yogev N, Mildner A, et al. Smad7 in T cells drives T helper 1 responses in multiple sclerosis and experimental autoimmune encephalomyelitis. Brain. 2010;133:1067-81.

27. Enders U, Lobb R, Pepinsky RB, Hartung HP, Toyka KV, Gold R. The role of the very late antigen-4 and its counterligand vascular cell adhesion molecule-1 in the pathogenesis of experimental autoimmune neuritis of the Lewis rat. Brain. 1998;121:1257-66.

28. Schmid H, Renner M, Dick HB, Joachim SC. Loss of inner retinal neurons after retinal ischemia in rats. Invest Ophthalmol Vis Sci. 2014;55:2777-87.

29. Shindler KS, Revere K, Dutt M, Ying GS, Chung DC. In vivo detection of experimental optic neuritis by pupillometry. Exp Eye Res. 2012;100:1-6.

30. Joachim SC, Gramlich OW, Laspas P, Schmid H, Beck S, von Pein HD, Dick $H B$, Pfeiffer N, Grus FH. Retinal ganglion cell loss is accompanied by antibody depositions and increased levels of microglia after immunization with retinal antigens. PLoS One. 2012;7:e40616.

31. Reinehr S, Kuehn S, Casola C, Koch D, Stute G, Grotegut P, Dick HB, Joachim SC. HSP27 immunization reinforces All amacrine cell and synapse damage induced by S100 in an autoimmune glaucoma model. Cell Tissue Res. 2018; 371(2):237-49.

32. Noristani R, Kuehn S, Stute G, Reinehr S, Stellbogen M, Dick HB, Joachim SC. Retinal and optic nerve damage is associated with early glial responses in an experimental autoimmune glaucoma model. J Mol Neurosci. 2016;58:470-82.

33. Reinehr S, Reinhard J, Gandej M, Kuehn S, Noristani R, Faissner A, Dick HB, Joachim SC. Simultaneous complement response via lectin pathway in retina and optic nerve in an experimental autoimmune glaucoma model. Front Cell Neurosci. 2016;10:140.

34. Pfaffl MW, Horgan GW, Dempfle L. Relative expression software tool (REST) for group-wise comparison and statistical analysis of relative expression results in real-time PCR. Nucleic Acids Res. 2002;30:e36

35. Bennett ML, Bennett FC, Liddelow SA, Ajami B, Zamanian JL, Fernhoff NB, Mulinyawe SB, Bohlen CJ, Adil A, Tucker A, et al. New tools for studying microglia in the mouse and human CNS. Proc Natl Acad Sci U S A. 2016; 113:E1738-46.

36. Karlstetter M, Walczak Y, Weigelt K, Ebert S, Van den Brulle J, Schwer H, Fuchshofer R, Langmann T. The novel activated microglia/macrophage WAP domain protein, AMWAP, acts as a counter-regulator of proinflammatory response. J Immunol. 2010;185:3379-90.

37. Karlstetter M, Sorusch N, Caramoy A, Dannhausen K, Aslanidis A, Fauser S, Boesl MR, Nagel-Wolfrum K, Tamm ER, Jagle $H$, et al. Disruption of the retinitis pigmentosa 28 gene Fam161a in mice affects photoreceptor ciliary structure and leads to progressive retinal degeneration. Hum Mol Genet. 2014;23:5197-210.

38. Scholz R, Caramoy A, Bhuckory MB, Rashid K, Chen M, Xu H, Grimm C, Langmann T. Targeting translocator protein (18 kDa) (TSPO) dampens pro-inflammatory microglia reactivity in the retina and protects from degeneration. J Neuroinflammation. 2015;12:201.

39. Lucchinetti C, Bruck W, Parisi J, Scheithauer B, Rodriguez M, Lassmann H. Heterogeneity of multiple sclerosis lesions: implications for the pathogenesis of demyelination. Ann Neurol. 2000;47:707-17.

40. Rasmussen S, Wang Y, Kivisakk P, Bronson RT, Meyer M, Imitola J, Khoury SJ. Persistent activation of microglia is associated with neuronal dysfunction of callosal projecting pathways and multiple sclerosis-like lesions in relapsing —remitting experimental autoimmune encephalomyelitis. Brain. 2007;130:2816-29.

41. Aharoni R, Saada R, Eilam R, Hayardeny L, Sela M, Arnon R. Oral treatment with laquinimod augments regulatory $T$-cells and brain-derived neurotrophic factor expression and reduces injury in the CNS of mice with experimental autoimmune encephalomyelitis. J Neuroimmunol. 2012;251:14-24.

42. Wegner C, Stadelmann C, Pfortner R, Raymond E, Feigelson S, Alon R, Timan B, Hayardeny L, Bruck W. Laquinimod interferes with migratory capacity of T cells and reduces IL-17 levels, inflammatory demyelination and acute axonal damage in mice with experimental autoimmune encephalomyelitis. J Neuroimmunol. 2010;227:133-43.

43. Yang JS, Xu LY, Xiao BG, Hedlund G, Link H. Laquinimod (ABR-215062) suppresses the development of experimental autoimmune encephalomyelitis, modulates the Th1/Th2 balance and induces the Th3 cytokine TGF-beta in Lewis rats. J Neuroimmunol. 2004;156:3-9.

44. Zilkha-Falb R, Gurevich M, Hayardeny $L$, Achiron A. The role of laquinimod in modulation of the immune response in relapsing-remitting multiple sclerosis: lessons from gene expression signatures. J Neuroimmunol. 2015; 283:11-6. 
45. Nimmerjahn A, Kirchhoff F, Helmchen F. Resting microglial cells are highly dynamic surveillants of brain parenchyma in vivo. Science. 2005:308:1314-8.

46. Ransohoff RM, Cardona AE. The myeloid cells of the central nervous system parenchyma. Nature. 2010;468:253-62

47. Hobom M, Storch MK, Weissert R, Maier K, Radhakrishnan A, Kramer B, Bahr $M$, Diem R. Mechanisms and time course of neuronal degeneration in experimental autoimmune encephalomyelitis. Brain Pathol. 2004;14:148-57.

48. Glass CK, Saijo K, Winner B, Marchetto MC, Gage FH. Mechanisms underlying inflammation in neurodegeneration. Cell. 2010;140:918-34.

49. Takeuchi H, Jin S, Wang J, Zhang G, Kawanokuchi J, Kuno R, Sonobe Y, Mizuno T, Suzumura A. Tumor necrosis factor-alpha induces neurotoxicity via glutamate release from hemichannels of activated microglia in an autocrine manner. J Biol Chem. 2006;281:21362-8.

50. Nikic I, Merkler D, Sorbara C, Brinkoetter M, Kreutzfeldt M, Bareyre FM, Bruck W, Bishop D, Misgeld T, Kerschensteiner M. A reversible form of axon damage in experimental autoimmune encephalomyelitis and multiple sclerosis. Nat Med. 2011:17:495-9.

51. Girolamo F, Ferrara G, Strippoli M, Rizzi M, Errede M, Trojano M, Perris R, Roncali L, Svelto M, Mennini T, Virgintino D. Cerebral cortex demyelination and oligodendrocyte precursor response to experimental autoimmune encephalomyelitis. Neurobiol Dis. 2011:43:678-89.

52. Kooi EJ, Strijbis EM, van der Valk P, Geurts JJ. Heterogeneity of cortical lesions in multiple sclerosis: clinical and pathologic implications. Neurology. 2012;79:1369-76.

53. Magliozzi R, Howell OW, Reeves C, Roncaroli F, Nicholas R, Serafini B, Aloisi $F$, Reynolds R. A gradient of neuronal loss and meningeal inflammation in multiple sclerosis. Ann Neurol. 2010;68:477-93.

54. Satoh J, Kino Y, Asahina N, Takitani M, Miyoshi J, Ishida T, Saito Y. TMEM119 marks a subset of microglia in the human brain. Neuropathology. 2016;36:39-49.

55. Zrzavy T, Hametner S, Wimmer I, Butovsky O, Weiner HL, Lassmann H. Loss of 'homeostatic' microglia and patterns of their activation in active multiple sclerosis. Brain. 2017;140:1900-13.

56. Mishra MK, Wang J, Keough MB, Fan Y, Silva C, Sloka S, Hayardeny L, Bruck W, Yong W. Laquinimod reduces neuroaxonal injury through inhibiting microglial activation. Ann Clin Transl Neurol. 2014;1:409-22.

57. Thone J, Ellrichmann G, Seubert S, Peruga I, Lee DH, Conrad R, Hayardeny L, Comi G, Wiese S, Linker RA, Gold R. Modulation of autoimmune demyelination by laquinimod via induction of brain-derived neurotrophic factor. Am J Pathol. 2012:180:267-74.

58. Ruffini F, Rossi S, Bergamaschi A, Brambilla E, Finardi A, Motta C, Studer V, Barbieri F, De Chiara V, Hayardeny L, et al. Laquinimod prevents inflammation-induced synaptic alterations occurring in experimental autoimmune encephalomyelitis. Mult Scler. 2013;19:1084-94.

59. Moore S, Khalaj AJ, Yoon J, Patel R, Hannsun G, Yoo T, Sasidhar M, MartinezTorres L, Hayardeny L, Tiwari-Woodruff SK. Therapeutic laquinimod treatment decreases inflammation, initiates axon remyelination, and improves motor deficit in a mouse model of multiple sclerosis. Brain Behav. 2013:3:664-82.

60. Sun D, Jakobs TC. Structural remodeling of astrocytes in the injured CNS. Neuroscientist. 2012;18:567-88.

61. Correale J, Farez MF. The role of astrocytes in multiple sclerosis progression. Front Neurol. 2015;6:180

62. Pekny M, Eliasson C, Chien $C L$, Kindblom LG, Liem R, Hamberger A, Betsholtz C. GFAP-deficient astrocytes are capable of stellation in vitro when cocultured with neurons and exhibit a reduced amount of intermediate filaments and an increased cell saturation density. Exp Cell Res. 1998;239:332-43.

63. Mayo L, Trauger SA, Blain M, Nadeau M, Patel B, Alvarez Jl, Mascanfroni ID, Yeste A, Kivisakk P, Kallas K, et al. Regulation of astrocyte activation by glycolipids drives chronic CNS inflammation. Nat Med. 2014;20:1147-56.

64. Bruck W, Pfortner R, Pham T, Zhang J, Hayardeny L, Piryatinsky V, Hanisch UK, Regen T, van Rossum D, Brakelmann L, et al. Reduced astrocytic NF-kappaB activation by laquinimod protects from cuprizone-induced demyelination. Acta Neuropathol. 2012;124:411-24.

65. Nakazawa T, Takeda M, Lewis GP, Cho KS, Jiao J, Wilhelmsson U, Fisher SK, Pekny M, Chen DF, Miller JW. Attenuated glial reactions and photoreceptor degeneration after retinal detachment in mice deficient in glial fibrillary acidic protein and vimentin. Invest Ophthalmol Vis Sci. 2007:48:2760-8.
66. Fairless R, Williams SK, Hoffmann DB, Stojic A, Hochmeister S, Schmitz F, Storch MK, Diem R. Preclinical retinal neurodegeneration in a model of multiple sclerosis. J Neurosci. 2012;32:5585-97.

67. Guan Y, Shindler KS, Tabuena P, Rostami AM. Retinal ganglion cell damage induced by spontaneous autoimmune optic neuritis in MOG-specific TCR transgenic mice. J Neuroimmunol. 2006;178:40-8.

68. Shindler KS, Ventura E, Dutt M, Rostami A. Inflammatory demyelination induces axonal injury and retinal ganglion cell apoptosis in experimental optic neuritis. Exp Eye Res. 2008;87:208-13.

69. Lidster K, Jackson SJ, Ahmed Z, Munro P, Coffey P, Giovannoni G, Baker MD, Baker D. Neuroprotection in a novel mouse model of multiple sclerosis. PLoS One. 2013;8:e79188.

70. Saidha S, Syc SB, Ibrahim MA, Eckstein C, Warner CV, Farrell SK, Oakley $J D$, Durbin MK, Meyer SA, Balcer LJ, et al. Primary retinal pathology in multiple sclerosis as detected by optical coherence tomography. Brain. 2011;134:518-33.

71. Brambilla R, Dvoriantchikova G, Barakat D, Ivanov D, Bethea JR, Shestopalov VI. Transgenic inhibition of astroglial NF-kappaB protects from optic nerve damage and retinal ganglion cell loss in experimental optic neuritis. J Neuroinflammation. 2012;9:213.

72. Green AJ, McQuaid S, Hauser SL, Allen IV, Lyness R. Ocular pathology in multiple sclerosis: retinal atrophy and inflammation irrespective of disease duration. Brain. 2010;133:1591-601.

73. Bruck W, Wegner C. Insight into the mechanism of laquinimod action. J Neurol Sci. 2011;306:173-9.

\section{Ready to submit your research? Choose BMC and benefit from:}

- fast, convenient online submission

- thorough peer review by experienced researchers in your field

- rapid publication on acceptance

- support for research data, including large and complex data types

- gold Open Access which fosters wider collaboration and increased citations

- maximum visibility for your research: over $100 \mathrm{M}$ website views per year

At BMC, research is always in progress.

Learn more biomedcentral.com/submissions 